\title{
The relationship between energy demand and real GDP growth rate: the role of price asymmetries and spatial externalities within 34 countries across the globe
}

\author{
Panagiotis Fotis ${ }^{\mathrm{a}}$ \\ Hellenic Competition Commission \\ Commissioner \\ Sotiris Karkalakos ${ }^{\mathrm{b}}$ \\ University of Piraeus and DePaul University \\ Department of Economics \\ Dimitrios Asteriou ${ }^{c}$ \\ Oxford Brookes University \\ Department of Accounting, Finance and Economics
}

\begin{abstract}
The aim of this paper is to empirically explore the relationship between energy demand and real Gross Domestic Product (GDP) growth and to investigate the role of regional externalities on per capita Final Energy Consumption (FEC) in 34 countries during the period from 2005 to 2013. The paper utilizes a Dynamic Panel Generalized Method of Moments (DPGGM) approach in order to analyse the effect of real GDP growth rate on FEC through an Error Correction Model (ECM) and spatial econometric techniques in order to examine clustered patterns of energy consumption. The results show that a) the demand is elastic both in the industrial and the household/services sectors, b) electricity and natural gas are demand substitutes, c) the relationship between real GDP growth rate and per capita energy consumption exhibits an inverted U-shape for all the sample countries under scrutiny (34 countries, Eurozone and EU28), but not for all the employed sectors of the economy, d) price (electricity and gas) and GDP growth asymmetries are supported from the employed parametric tests, and, e) distance does not affect per capita FEC, but economic neighbours have a strong positive effect.
\end{abstract}

Keywords: Energy Demand - Income nexus; DPDGMM; error correction model; spatial externalities; EU34 - EU28 - Eurozone.

JEL classification C21; C23; C51; L16; R12

\footnotetext{
a Corresponding Author, Hellenic Competition Commission, Commissionner, 5 P. Ioakim St., 12132, Peristeri, Greece, Tel.: +30 6947609741, E-mail: p1972fo@gmail.com. The views expressed herein are strictly and purely those of the authors.

${ }^{\mathbf{b}}$ University of Piraeus, Department of Economics, 80, M. Karaoli \& A. Dimitriou St., 18534, Piraeus, Greece, Tel.: +30 2104142288, E-mail: sotkar@unipi.gr

c Oxford Brookes University. Department of Accounting, Finance and Economics, Programme Lead for Economics, Oxford Brookes University, Wheatley Campus, Wheatley, Oxford, OX33 1HX, Tel.: +44 (0) 1865 485837, E-mail: dasteriou@brookes.ac.uk
} 


\section{Introduction}

In 2013 energy consumption within European Union (EU) fell back to its 1990's level (1. 666 million tones of oil equivalent - MTOE) and down by $9.1 \%$ to its 2006 peak. The amount of energy that EU must import to satisfy its consumption needs was $53 \%$ the same year (European Union 2015). At the same time European Commission estimates that GDP growth rate will be on average $1.6 \%$ over the period 2015-2030, while lower growth rates are assumed (on average 1.4\%) in the longer term (2013-2015). ${ }^{1}$

A recent analysis of per capita energy consumption (tones of oil equivalent per capita) versus GDP per capita (2011 USD PPP) by European Environmental Agency (2015) has shown mixed results regarding the correlation between energy consumption and GDP. Particularly, some countries such as Canada, United States and Australia depict positive relationship between energy consumption and GDP, while others such as Italy, Turkey, Brazil and India exhibit low levels of energy consumption to GDP per capita.

The motivation of this paper stems from the traditional Kuznets curve (Kuznets 1955). According to it, as per capita income increases, at the beginning income inequality also increases but after some turning points it starts declining. In other words, at lower levels of per capita income its distribution is skewed to higher income levels, but skewness is reduced as per capita income increases. This relationship is represented by an inverted U-shaped relationship.

The environmental version of traditional Kuznets curve (Environmental Kuznets Curve, $\mathrm{EKC})^{2}$ follows a similar line of reasoning. EKC basically states that the relationship between energy intensity or consumption and income level has an inverted U-shape. ${ }^{3}$ Medlock and

\footnotetext{
${ }^{1}$ See European Commission (2013), p 14.

${ }^{2}$ For more details see the papers by Shafik and Bandyopandhyay (1992), Grossman and Krueger (1995) and Holtz-Eakin and Selten (1995).

${ }^{3}$ Recent work on the validity of EKC can be found in Alvarez, Marrero and Puch (2005), Richmond and Kaufmann (2006), Coondoo and Dinda (2008), Soytas and Sari (2009), Acaravci and Ozturk (2010), Marrero (2010), Jaunky (2011), Arouri et al. (2012a, 2012b), Esteve and Tamarit (2012), Fosten et al.(2012), Donfouet et
} 
Soligo (2001) and Galli (1998), among others, have found a non-monotonic relationship between energy intensity and real Gross Domestic Product (GDP). It is assumed that there is a point of real GDP growth rate at which beyond this point FEC begins to decline as growth rate continues to rise.

Based on the above findings, this paper adopts the EKC methodology to empirically explore the existence or not of a non-monotonic relationship (inverted U-shape) between per capita Final Energy Consumption (FEC) and real per capita GDP growth rate and to investigate the role of asymmetries (price and GDP growth asymmetries) and regional externalities on FEC for an updated panel data set of 34 countries (EU 28 countries, 5 candidates - Montenegro, FYROM, Albania, Serbia, Turkey - and Norway). The time period spans from 2005 to 2013. For these purposes we employ yearly data and a Dynamic Panel Generalized Method of Moments (DPGMM) approach in an Error Correction Model (ECM) and we use spatial econometric techniques to examine clustered patterns of energy consumption. Also, we utilise parametric tests (Wald tests, F-tests and Impulse response functions) in order to examine the asymmetric responses of prices and real per capita GDP growth rate on per capita FEC.

The paper contributes in four different angles: a) it examines the effect of spatial externalities on FEC per capita, b) it examines the price (electricity and gas) and real GDP growth rate per capita asymmetric adjustment paths, c) it provides an investigation of the competitive pressures that natural gas may impose on electricity by presenting own and cross price elasticities in the industrial and household sectors of the countries under examination, and, d) it extents the literature regarding the relationship between energy consumption and

al. (2013), Sephton and Mann (2013), Shahbaz et al. (2013), Danaeifar (2014), Ozturk and Al-Mulali (2015), Ajmi et al.(2015), Rodriquez et al. (2016), Polemis and Stengos (forthcoming), Apergis (2016) and Sephton and Mann (2016). For a survey of the EKCs on an empirical and theoretical perspective prior to 2000 see the relevant studies of Lopez-Menendez et al. (2014), Dinda (2004), Stern (2014). Panayotou (1995; 2000) has also given a critical overview of the research done from 1992 to 2000. 
GDP growth rate per capita. To the best of our knowledge the first contribution of this paper has not been analysed so far in the literature.

The remainder of this paper is organized in the following way. Section 2 reviews the literature and section 3 presents the data and descriptive statistics of the employed variables. Sections 4 and 5 present the methodology and the empirical models that are utilised and section 6 reports the empirical results and the parametric tests for price and growth asymmetric responses. Lastly, section 7 concludes.

\section{Literature Review}

In this paper we mainly focus on the relationship between energy intensity or consumption and income level. A strand of this literature is occupied with the casual relationship between energy consumption and income level. Narayan (2016) uses a panel data of 135 countries and concludes that empirical findings strongly support the neutrality hypothesis between energy consumption and economic growth. However, the empirical results for a panel of 35 middle-income countries show that energy consumption predicts real GDP per capita. Polemis and Dagoumas (2013) have found that the causal relationship between electricity consumption and economic growth in Greece is bi-directional. They also state that in the long-run electricity demand appears to be price inelastic and income elastic, while in the short-run the relevant elasticities are both below unity. Maggazino (2015) states that in the short-run the flow of causality in Italy runs from energy use to GDP, and there is a long-run bidirectional causal relationship between the two variables. Therefore, he concludes that energy is a limiting factor to GDP growth.

Jakob et al. (2012) use a difference-in-difference estimator on panel data for 51 countries from 1972 to 2005 . They examine the relationship between income growth, measured by market exchange rates, and primary energy consumption. They find that the elasticity of total primary energy use with respect to income is 0.631 for developing countries. However, the 
corresponding value for developed countries is 0.181 but statistically non-significant. On the contrary, Soytas and Sari (2003) use cross-section and panel data in the top 10 emerging markets and G-7 countries and conclude that elasticity of energy consumption with respect to GDP is significantly above one (namely 1.35 ). ${ }^{4}$ The authors have also discovered bidirectional causality in Argentina, causality running from GDP to energy consumption in Italy and Korea, and from energy consumption to GDP in Turkey, France, Germany and Japan. 5

Another strand of the literature examines the validity of EKC. Particularly, Brookes (1972) uses cross section data for 22 countries from 1950 to 1965 and estimates that the income elasticity for the less developed income countries were considerably higher than for the developed countries. Even though Brookes (1972) utilizes a log-log linear model his findings eventually support the idea of a non-monotonic relationship between per capita energy consumption and per capita GDP. Zilberfarb and Adams (1981) use panel data to examine the relationship between energy consumption and GDP in 47 developing countries over the period 1970 to 1976 . The empirical results show that the elasticity of energy consumption with respect to GDP remains stable and significantly above unity over the scrutinized period and particularly in developing countries it is around 1.35. Ang (1987) found that for 100 countries in 1975 energy elasticity is about unity for the low-income developing countries, between 1.6 and 1.8 for the high-income developing countries, and

\footnotetext{
${ }^{4}$ Desai (1986) has found that the GDP elasticity of energy consumption for LDCs is found to be less than one. ${ }^{5}$ See also, inter alia, Asafu-Adjaye (2000); Lee (2005); Wolde-Rufael (2006); Mahadevan and Asafu-Adjaye (2007); Mechrara (2007); Hannesson (2009); Payne (2010); Pirlogea and Sicea (2012); Fuinhas and Margues (2012); Apergis and Tang (2013); Ouedraogo (2013); Hamdi et al. (2014).

${ }^{6}$ Other researchers utilize econometric and non-econometric tools in order to decompose the main determinants of energy intensity. Schäfer (2005) finds similar results with those of Judson et al. (1999) regarding household and industrial sectors and shows that in the service sector energy consumption decreases monotonically with national income. See also Boyd et al. (1987); Metcalf (2008); Wing (2008) and Nillesen et al. (2013), ch. 3, pp 93.
} 
decreases slightly thereafter for the industrial countries. These findings support the idea of a bell shape relationship between energy consumption and GDP. ${ }^{7}$

Galli (1998) estimates the long term trends of energy intensity in 10 emerging Asian countries from 1973 to 1990 by using a quadratic (non-monotonic) function of log income. The author finds a change in trend of energy intensity as GDP increases indicating an inverted U-shaped pattern. Judson et al. (1999) examine a panel data of 123 OECD countries from 1970 to 1991 . Their findings suggest that energy consumption tends to fall (increase) as national income falls (increases) in the household (transportation) sector, while in the industry sector the share of energy consumption with respect to income tends to follow a bell shape (an inverted U-shape). The study by Medlock and Soligo (2001) for a panel of data of 28 countries (9 countries from the Asian/Pacific geographic region, 15 European countries ${ }^{8}$ and 4 countries from North/South America) during the period 1978-1995 verifies the empirical findings by Judson et al. (1999) regarding the transportation and industry sectors, while the share of energy consumption with respect to national income in the household sector rises at the beginning and then levels out.

Lescaroux (2011) empirically estimates different sectors and regions for a panel of 101 countries and he concludes that the inverse U-shaped relationship between energy intensity and income is not supported by his findings for all sectors of the economy in the long-run. Particularly, energy intensity exhibits a bell shape in industrial and services sectors, but not in road motor fuel and residential sectors. The long-run equilibrium path of energy intensity is strictly decreasing as residential demand accounts for most of end-use demand. Wealth, temperature (in the residential sector), income inequality (in the residential and road transportation sectors), price (in the services sector), exogenous efficiency gains (in the industrial sector) and other factors such as industrial structure or consumer behaviour are the

\footnotetext{
${ }^{7}$ For a time-series analysis of individual non-oil developing country see Pourgerami and Hirschhausen (1991).

${ }^{8}$ Turkey, Greece, Portugal, Spain, Ireland, Austria, Italy, Belgium, Netherlands, UK, France, Finland, Sweden, Denmark, Norway.
} 
main drivers of energy consumption. Concerning commercial energy intensity, even thought previous studies have shown it exhibits an inverted U-shaped relationship, Lescaroux (2011) states that various shapes of this relationship may emerge (decreasing, $U$, inverted $U$ and inverted $\mathrm{N}$ shapes) depending on the initial conditions of the economy, the short-term dynamics or other catch-up effects that may intervene such us the substitution of non commercial by modern fuels or the increase of the popularity of passenger cars in the Western countries.

Nillesen et al. (2013) provide a global perspective on the development of energy efficiency by analysing 65 developing and developed countries from 1971 to 2009. The authors use a GMM estimation method to explore the relationship between energy intensity and income level and divide the sample of countries into four groups: poor, low-income, middle-income and high-income countries. The regressions show the absence of an inverted U-shaped relationship in the most of the countries under scrutiny since energy consumption is positively affected by increases in population, GDP rate (income per capita). According to the authors this outcome may be the result of the diffusion of new techniques and know-how among countries. Table 1 summarizes the empirical results per sector of economy regarding the relationship between energy consumption and income.

Table 1: The relationship between energy consumption and income per sector of the economy

\begin{tabular}{|c|c|c|c|c|}
\hline \multirow[t]{2}{*}{ Papers } & \multicolumn{4}{|c|}{ Sectors of the Economy } \\
\hline & Whole Economy & Industrial & Residential & Services \\
\hline Brookes (1972) & Non - monotonic relationship & & & \\
\hline $\begin{array}{l}\text { Zilberfarb and } \\
\text { Adams (1981) }\end{array}$ & Monotonic relationship & & & \\
\hline Ang (1987) & Non - monotonic relationship & & & \\
\hline Gali (1998) & Inverted U-shaped pattern & & & \\
\hline $\begin{array}{c}\text { Judson et al. } \\
(1999)\end{array}$ & & $\begin{array}{c}\text { Inverted U-shaped } \\
\text { pattern }\end{array}$ & Monotonic relationship $^{1}$ & \\
\hline $\begin{array}{l}\text { Medlock and } \\
\text { Soligo (2001) } \\
\end{array}$ & & $\begin{array}{c}\text { Inverted U-shaped } \\
\text { pattern }\end{array}$ & $\begin{array}{l}\text { Rises at the beginning } \\
\text { and then levels out }{ }^{2}\end{array}$ & \\
\hline $\begin{array}{l}\text { Lescaroux } \\
(2011)\end{array}$ & & $\begin{array}{l}\text { Inverted U-shaped } \\
\text { pattern }\end{array}$ & $\begin{array}{l}\text { Monotonic relationship } \\
\text { (strictly decreasing) }^{3}\end{array}$ & $\begin{array}{l}\text { Inverted U-shaped } \\
\text { pattern }\end{array}$ \\
\hline $\begin{array}{l}\text { Nillesen et al. } \\
\quad \text { (2013) }\end{array}$ & $\begin{array}{l}\text { A non - pronounced U } \\
\text { shaped pattern }\end{array}$ & & & \\
\hline
\end{tabular}

Notes: ${ }^{1}$ The monotonic relationship also holds in the transportation sector, ${ }^{2}$ In the transportation sector there exists a monotonic relationship, ${ }^{3}$ The same seems to hold in the road fuel sector in the long-run.

Source: Authors' elaboration of data 


\section{The Data Set}

\subsection{Data description}

The econometric estimations are based on pooled time-series cross-section yearly (panel) data for 34 countries ( 28 EU countries, 5 candidates and Norway) covering the period from 2005 to $2013(\mathrm{~T}=9, \mathrm{~N}=34)$. The sample consists of an updated yearly data set that allows us to carry out a thorough investigation of energy demand, its relationship with GDP (income) growth, potential price and growth asymmetries and regional externalities in different sectors of national economies. The data source is Eurostat.

The reason for using a panel data set so as to investigate possible cointegrating vectors instead of time series analysis is that residual based cointegration tests are known to have low power and are subject to normalization problems. Since economic time series are typically short, it is desirable to exploit panel data in order to draw sharper inferences (Christopoulos and Tsionas, 2003, Polemis and Dragoumas, 2013). Besides, cross-section data suffers from assuming that the same characteristics (i.e. structure of the markets, degree of regulation, etc.) apply to all national economies, while there are difficulties in obtaining reliable time-series data of sufficient length.

\subsection{Descriptive statistics}

The panel data of 34 countries covering 8 years used in this paper could help gain insight into whether an EKC exists. Table 2 presents the average values of per capita $F E C$, electricity and gas prices and real per capita GDP growth rates for the all the countries examined in the study. We also divide the sample of countries into 2 sub-groups (Eurozone and EU 28) in order to compare and contrast the aforementioned averages for each group.

Particularly, in the Eurozone the average real per capita GDP growth rate for the period 2005-2013 was 1.23 while the corresponding figures for per capita FEC were 2.25 Euro per MWh in the industry and 3.44 Euro per MWh in the Household/Services sectors. In the EU 
28 countries the corresponding values were 1.40 for real per capita GDP growth rate and 2.45 (Industry) and 3.60 (Household/Services) Euro per MWh for per capita FEC. When we incorporate the 5 candidates countries (Montenegro, FYROM, Albania, Serbia, Turkey) and Norway into the analysis the figures are slightly above the EU 28 averages (real per capita GDP growth rate: 1.69; per capita FEC-Industry: 2.63; FEC-Household/Services: 3.64).

When we examine the relationship of per capita FEC and real per capita GDP growth rate separately for each country of the sample some important remarks emerge. Countries with the highest values of average real per capita GDP growth rate (Bulgaria, Czech Republic, Estonia, Latvia, Lithuania, Malta, Poland, Romania, Slovakia and Serbia) present low levels of per capita energy consumption. ${ }^{9}$ This may imply a shift of structural changes in the economies towards environmental friendly energy use practices. Technological developments at both demand and supply sides of energy, such as end-use appliances, and their diffusion among countries play a crucial role since the increase of energy consumption becomes less pronounced as economic development starts to rise (Nillesen et al., 2013).

However, countries with low values of average real GDP growth rate (for instance, Finland, Sweden, UK, Norway, Slovenia, Austria and Italy) exhibit high levels of per capita energy consumption. Particularly, the average real GDP growth rate for Finland is 0.81 and per capita FEC in the Industry and Household/Services sectors for the same country is 7.63 and 7.30 Euro per MWh respectively. Besides, in Norway the average real GDP growth rate is 1.29 and per capita FEC in the Industry and Household/Services sectors are 9.56 and 12.81 Euro per MWh respectively. Even more, countries with negative average real per capita GDP growth rate (Greece, Italy and Portugal) exhibit moderate values of per capita $F E C$ during the period 2005-2013. For instance, in Greece, per capita FEC in the Household/Services sectors

\footnotetext{
${ }^{9}$ The exception that justifies the rule is Luxembourg where the average real per capita GDP growth rate for the period under scrutiny is 2.18 and FEC in Industry and Household/Services sectors is 6.51 and 5.96 Euro per MWh respectively.
} 
is almost at the Eurozone average level (3.41), while in Italy, per capita $F E C$ in the industrial

sector is slightly below from the Eurozone average level (2.21).

Table 2: Average values of all variables: 2005 - 2013

\begin{tabular}{|c|c|c|c|c|c|c|c|c|c|c|}
\hline \multirow[t]{2}{*}{ Country } & \multicolumn{3}{|c|}{ Energy Consumption $\neq$} & \multicolumn{3}{|c|}{ Electricity Price $\neq$} & \multicolumn{3}{|c|}{ Gas Price ${ }^{\ddagger}$} & \multirow{2}{*}{$\begin{array}{c}\text { Real per capita } \\
\text { GDP Growth } \\
\text { Rate }^{\ddagger}\end{array}$} \\
\hline & Industry & House/Ser & All & Industry & House/Ser & All & Industry & House/Ser & All & \\
\hline Total sample & 2.63 & 3.64 & 6.33 & 65.32 & 110.51 & 91.62 & 32.33 & 42.57 & 34.60 & 1.69 \\
\hline$E U 28$ & 2.45 & 3.60 & 5.79 & 86.39 & 146.79 & 114.73 & 30.51 & 52.90 & 34.91 & 1.40 \\
\hline Eurozone & 2.25 & 3.44 & 6.16 & 90.23 & 151.43 & 118.10 & 31.79 & 54.03 & 73.90 & 1.23 \\
\hline \multicolumn{11}{|c|}{28 countries of the European Union } \\
\hline Belgium $^{\uparrow,}{ }^{* *}$ & 3.45 & 3.79 & 7.39 & 89.30 & 184.9 & 137.1 & 28.67 & 55.01 & 41.84 & 1.13 \\
\hline Bulgaria & 1.17 & 2.28 & 3.51 & 56.84 & 73.83 & 65.33 & 24.24 & 37.32 & 31.20 & 2.55 \\
\hline Czech Rep. ${ }^{* * *}$ & 2.18 & 2.95 & 5.34 & 91.48 & 123.6 & 107.5 & 28.87 & 45.94 & 44.94 & 2.12 \\
\hline Denmark $^{* *}$ & 1.65 & 4.09 & 5.80 & 76.19 & 263.3 & 169.7 & 25.64 & 97.85 & 56.02 & 0.31 \\
\hline Germany $^{\ddagger},{ }^{* *}$ & 2.73 & 3.42 & 6.30 & 88.32 & 223.1 & 155.7 & 36.44 & 59.79 & 34.62 & 1.23 \\
\hline Estonia $^{\uparrow},{ }^{* *}$ & 1.57 & 3.19 & 3.19 & 56.58 & 88.52 & 72.55 & 22.34 & 33.00 & 27.01 & 2.64 \\
\hline Ireland $^{\dagger},{ }^{* *}$ & 1.95 & 3.67 & 3.67 & 114.3 & 182.1 & 148.2 & 34.92 & 57.46 & 15.83 & 1.02 \\
\hline Greece $^{\dagger},{ }^{* *}$ & 1.22 & 3.41 & 4.65 & 83.12 & 105.5 & 94.35 & 48.18 & 77.85 & 37.05 & -2.12 \\
\hline $\operatorname{Spain}^{\uparrow,}{ }^{* *}$ & 1.81 & 3.34 & 5.24 & 95.13 & 158.1 & 126.6 & 28.18 & 55.40 & 42.53 & 0.56 \\
\hline France $^{\ddagger},{ }^{* *}$ & 1.88 & 4.50 & 6.58 & 64.12 & 126.3 & 95.23 & 31.92 & 52.57 & 31.93 & 0.91 \\
\hline Croatia & 0.78 & 2.66 & 3.49 & 75.97 & 105.1 & 90.55 & 30.52 & 33.34 & 44.36 & 0.41 \\
\hline Italy $^{\ddagger},{ }^{* *}$ & 2.21 & 2.62 & 5.01 & 102.3 & 209.5 & 103.9 & 30.61 & 66.69 & 3.36 & -0.47 \\
\hline Cyprus $^{\uparrow}$ & 0.68 & 4.75 & 5.44 & 138.9 & 181.3 & 160.1 & - & - & - & 0.94 \\
\hline Latvia $^{\uparrow}$ & 0.77 & 2.00 & 2.84 & 72.32 & 98.79 & 85.56 & 26.08 & 34.50 & 30.93 & 2.69 \\
\hline Lithuania $^{\dagger}$ & 0.86 & 1.74 & 2.63 & 79.52 & 96.82 & 88.17 & 29.03 & 36.11 & 38.92 & 2.52 \\
\hline Lux/bourg ${ }^{\uparrow},{ }^{* *}$ & 6.51 & 5.96 & 12.70 & 91.73 & 163.5 & 127.6 & 38.04 & 46.53 & 38.92 & 2.18 \\
\hline Hungary $^{* *}$ & 0.91 & 2.16 & 3.23 & 89.63 & 135.5 & 112.5 & 31.34 & 37.82 & 37.62 & 0.63 \\
\hline Malta $^{\dagger}$ & 1.10 & 3.29 & 4.39 & 135.5 & 130.9 & 133.2 & - & - & 46.52 & 2.33 \\
\hline Netherlands $^{\uparrow},{ }^{* *}$ & 2.33 & 3.92 & 6.35 & 84.77 & 187.9 & 136.3 & 28.06 & 67.56 & 33.79 & 1.05 \\
\hline Austria $^{\uparrow},{ }^{* *}$ & 3.17 & 3.67 & 7.23 & 82.41 & 174.2 & 128.3 & 30.70 & 62.05 & 43.69 & 1.40 \\
\hline Poland $^{* *}$ & 1.12 & 1.78 & 2.99 & 74.67 & 125.3 & 99.99 & 28.31 & 39.27 & 25.21 & 3.84 \\
\hline Portugal $^{\uparrow},{ }^{* *}$ & 1.59 & 2.82 & 4.45 & 86.91 & 159.4 & 123.1 & 31.35 & 59.99 & 45.25 & -0.38 \\
\hline Romania & 0.99 & 0.84 & 1.89 & 79.19 & 98.14 & 88.66 & 18.25 & 26.73 & 28.32 & 2.63 \\
\hline Slovenia $^{\uparrow},{ }^{* *}$ & 3.02 & 2.93 & 6.04 & 80.48 & 126.2 & 103.3 & 35.15 & 57.51 & 42.22 & 1.10 \\
\hline Slovakia $^{\natural,}{ }^{* *}$ & 2.10 & 2.17 & 4.37 & 107.8 & 150.9 & 129.3 & 31.13 & 42.40 & 48.19 & 3.91 \\
\hline Finland $^{\mathfrak{\uparrow}, ~}{ }^{* *}$ & 7.63 & 7.30 & 15.06 & 60.68 & 128.3 & 94.53 & 29.60 & - & 41.93 & 0.81 \\
\hline Sweden $^{* *}$ & 5.87 & 7.48 & 13.63 & 69.14 & 174.2 & 121.6 & 39.02 & 99.67 & - & 1.63 \\
\hline$U K^{* *}$ & 1.68 & 3.47 & 5.21 & 91.27 & 133.8 & 112.5 & 27.63 & 40.02 & 19.20 & 1.05 \\
\hline \multicolumn{11}{|c|}{6 countries (5 candidates of European Union) } \\
\hline Norway $^{*-2}$ & 9.56 & 12.81 & 22.50 & 71.43 & 176.2 & 123.8 & - & - & - & 1.29 \\
\hline Montenegro & 3.41 & 2.02 & 5.47 & 66.23 & 88.75 & 77.49 & - & - & - & - \\
\hline FYROM $^{* * *}$ & 1.03 & 2.13 & 3.17 & 38.64 & 80.06 & 59.35 & 38.41 & - & 60.05 & - \\
\hline Albania & 0.29 & 1.36 & 1.66 & - & - & - & - & - & - & - \\
\hline Serbia & 0.92 & 2.62 & 3.59 & 55.72 & 55.33 & 55.53 & 36.88 & - & 56.06 & 2.39 \\
\hline Turkey $^{* * *}$ & 0.97 & 1.12 & 2.11 & 73.47 & 115.9 & 94.68 & 23.52 & 32.23 & 102.2 & - \\
\hline
\end{tabular}

Notes: 'Eurozone, ${ }^{* *}$ OECD member countries, ${ }^{* * *}$ Former Yugoslav Republic of Macedonia, $\neq$ The explanation of the variables is given in Table 2 in the Appendix.

Electricity \& Gas Price: Euro per MWh, Real GDP Growth Rate: Annual growth rate of GDP volume (percentage change on previous year), Final Energy Consumption: consumption per MWh (per capita).

Source: Authors' elaboration of data from European Commission, Eurostat (http://ec.europa.eu/eurostat/web/energy/data). 
The above mentioned statistical evidences clearly support the idea of the existence of a non-monotonic relationship between per capita FEC and real GDP growth rate. This relationship exhibits an inverted U-shaped pattern, which is supported by figures 1 and 2 .

Figure 1: The relationship between the Final Energy Consumption and the Real GDP Growth Rate for 34 countries between 2005 - 2013: Industry, Households/Services and All sectors (Industry \& Households/Services)
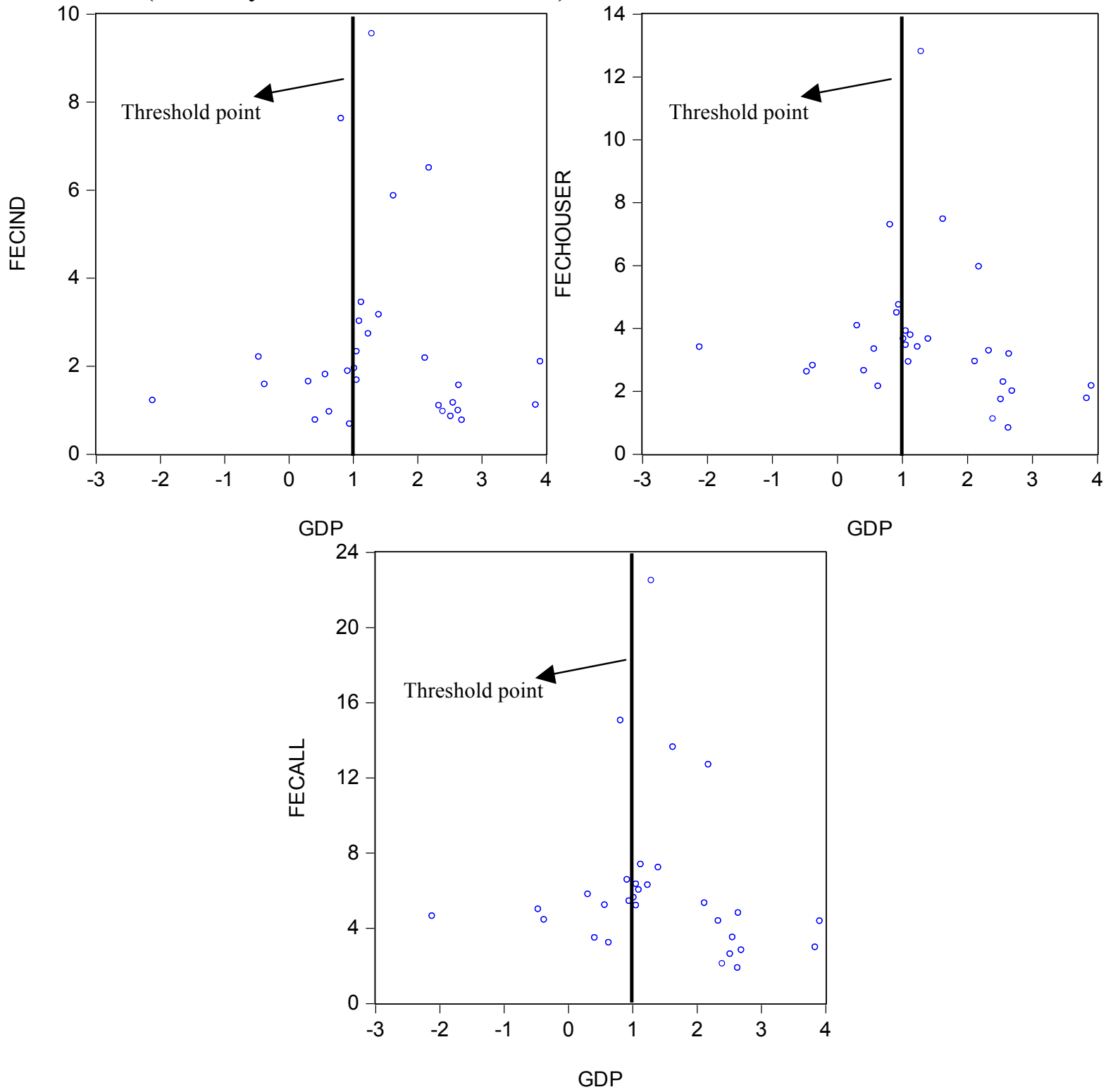

Notes:

For all the graphs the horizontal axis depicts the Real GDP Growth Rate at 2005 constant prices (volume) and the vertical axis depicts the average (2005 - 2013) Final Energy Consumption per capita at 2005 constant prices (MWh).

FECIND: Final Energy Consumption in the Industry, FECHOUSER: Final Energy Consumption in the Household/Service sectors, GDP: Real GDP Growth rate

Source:

Authors' elaboration of data from European Commission, Eurostat (http://ec.europa.eu/eurostat/web/energy/data). 
Especially, figure 1 shows the relationship of per capita $F E C$ with respect to real per capita GDP growth rate for the scrutinized countries and figure 2 presents the same relationship for the EU28 countries and the Eurozone. Visual inspection of figure 1 supports an inverted U-shaped relationship between the two variables. The possible threshold point for this non-monotonic relationship seems to be around 1\% of real per capita GDP growth rate. The graph shows that the majority of the sample countries, except some outliers, ${ }^{10}$ exhibit high levels of real per capita GDP growth rate with low or at least modest levels of per capita FEC

Figure 2: The relationship between the Final Energy Consumption and the Real GDP Growth Rate for EU 28 countries \& Eurozone between 2005 - 2013: Industry, Households/Services and All sectors (Industry \& Households/Services)
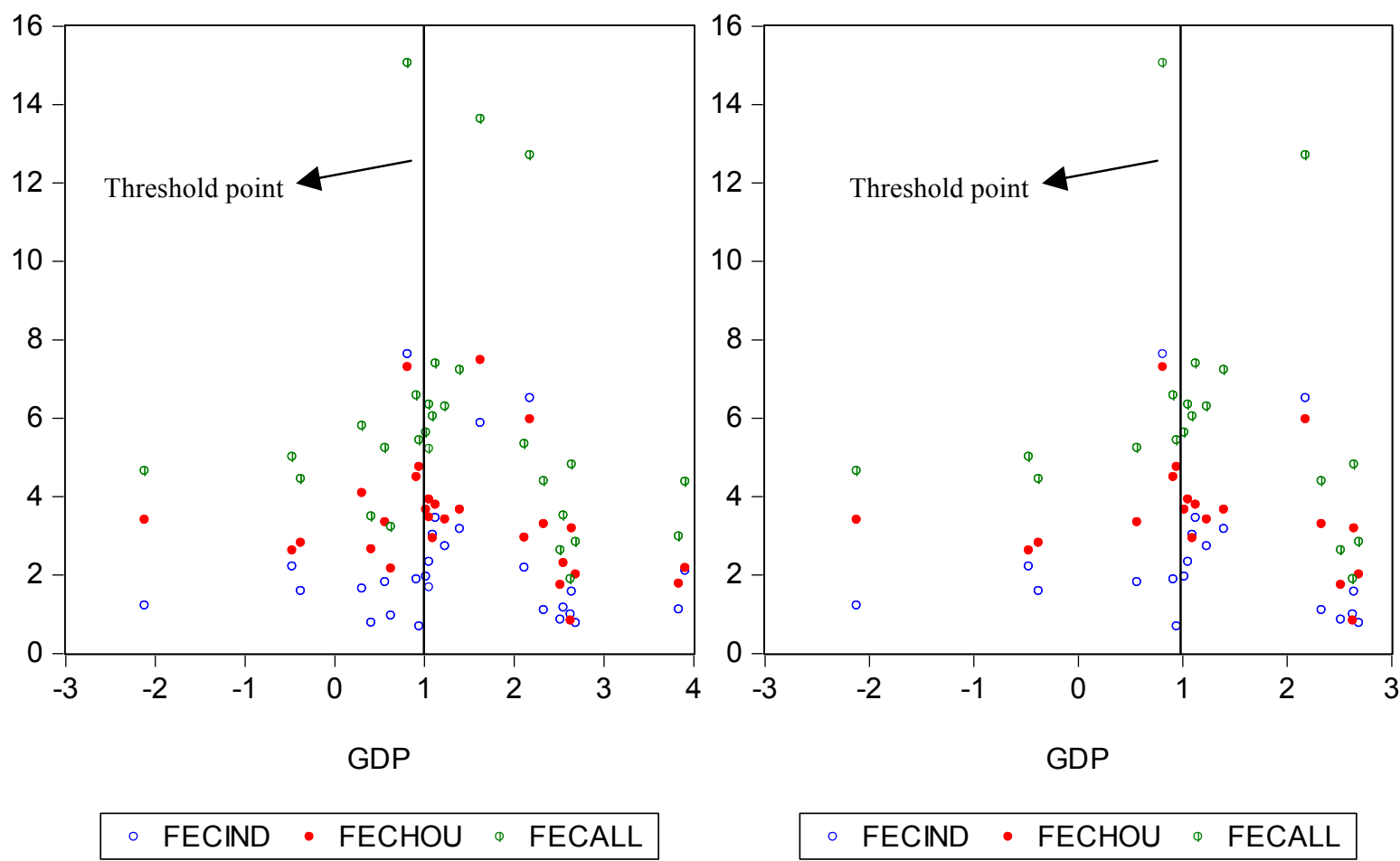

Notes:

The left graph shows the relationship between the Final Energy Consumption and the Real GDP Growth Rate for EU 28 countries and the right graph shows the corresponding relationship for the Eurozone. The horizontal axis depicts the Real GDP Growth Rate at 2005 constant prices (volume) and the vertical axis depicts the average (2005 - 2013) Final Energy Consumption per capita at 2005 constant prices (MWh).

FECIND: Final Energy Consumption in the Industry, FECHOUSER: Final Energy Consumption in the Household/Service sectors, GDP: Real GDP Growth rate

Source: Authors' elaboration of data from European Commission, Eurostat (http://ec.europa.eu/eurostat/web/energy/data).

\footnotetext{
${ }^{10}$ Figures without the outliers are not reported here for economy of space. They are available from authors upon request.
} 
Similarly, the bell shape relationship between the two variables is supported from the visual inspection of figure 2, either, even in the case we remove the outliers from the employed data. It is evident from figure 2 (both for the Eurozone and the EU28 countries) that per capita $F E C$ increases until real per capita GDP growth rate reaches $1 \%$ and then starts to decrease on average.

\section{Dynamic Modelling}

Ahn and Schmidt (1995) argue that the instrumental variables approach by Anderson and Hsiao (1982) fails to take all of the potential orthogonality conditions into account as well as the differenced structure on the residual disturbances (Baltagi 2005, p. 145). Therefore, the estimator by Anderson and Hsiao (1982) leads to consistent but not necessarily efficient estimates of the parameters in the model. Arellano (1989) also argues that for dynamic error components models, the estimator that uses differences rather than levels for instruments has a singularity point and very large variances over a significant range of parameter values (Baltagi 2005, p. 136).

In order to allow for the dynamic aspects in our models we investigate our main research questions by using dynamic panel data techniques such as the DPGMM estimator attributed to Arellano and Bond (1991). ${ }^{11}$ The DPGMM estimator by Arellano and Bond (1991) is also known as a two - step difference GMM (DIFGMM) where the lagged levels of the regressors are instruments for the equations in first differences. It is worth mentioning that among the GMM estimators, the estimator by Arellano and Bond (1991) is the most widely applied in empirical analysis (Gutierrez, 2003). ${ }^{12}$ The DIF-GMM estimator is designed to deal with small $\mathrm{T}$ and large $\mathrm{N}$ panels, that is, few time periods and many individual units (cross

\footnotetext{
${ }^{11}$ See also Holtz-Eakin et al. (1988).

${ }^{12}$ See Table A1 in the Appendix which presents the methodology employed of the main literature review in the last 18 years.
} 
sections). Recall that in this paper we deal with a short $\mathrm{T}$ dynamic panel data $(\mathrm{T}=9$ and $\mathrm{N}=34$ ).

The DPGMM estimator by Arellano and Bond (1991) also help us to deal with possible endogeneity issues. The inclusion of the real GDP growth rate as an indicator of the level of income in the European countries might raise a possible endogeneity issues, since there is an open debate in the empirical literature whether the direction of the causality runs from growth to electricity consumption or vice versa (see Section $2) .^{13}$

In order to investigate the short-run equilibrium in the national energy markets and especially in the specific sectors under scrutiny (Industry and Household/Services) we employed ECMs attributed to Engle and Granger (1987). This is a two-stage procedure in which the first step corresponds to three multiequational long-run models (Industry, Household/Services and all sectors) applying DGMM and the second stage corresponds to the estimation of three short-run models (Industry, Household/Services and all of them) including the long-run relations estimated in the previous step. The basic statistical assumption underlying this approach is that the variables are stationary with the first two moments of the underlying data generation process not depending on time. For this to be true we first have to check for the presence of unit roots. If variables are non-stationary I(1) processes, then a linear combination may exist which may well be a stationary $\mathrm{I}(0)$ process. If this is the case then the variables are cointegrated. Using an ECM, short and long-run effects can be captured by estimating the short and long-run elasticities, respectively.

\footnotetext{
${ }^{13}$ On the contrary, threshold cointegration models, such as those by Hansen and Seo (2002) and Hansen (2000) treat the threshold variable (real per capita GDP growth rate here) as exogenous (Caner and Hansen, 2004).
} 
Following the standard literature crucial determinants of energy demand are GDP (or income) and prices. In this paper we employ real per capita GDP growth rate, electricity and gas prices as independent variables in the following basic quadratic energy demand function with 5 lags as GMM instruments in order to derive the longrun equilibrium: ${ }^{14}$

$$
\log F E C_{t, i}=\alpha_{i}+\alpha_{1} \log E P_{t, i}+\alpha_{2} \log G P_{t, i}+\alpha_{3} G R_{t, i}+\alpha_{4} G R_{t, i}^{2}+\varepsilon_{t, i}
$$

where $\log F E C_{t, i}$ denotes the natural logarithm of Final Energy Consumption per capita, $\log E P_{t, i}$ is the natural logarithm of Electricity Price and $\log G P_{t, i}$ stands for the natural logarithm of Gas Price. ${ }^{15}$ The three aforementioned logarithm variables are sector-specific. However, $G R_{t, i}$, which depicts real GDP growth rate in percentage terms from the previous year, is not a sector-specific variable. Finally, following standard notation $t$ stands for the period and $i$ stands for the countries under scrutiny. All the variables are measured in MWh at 2005 constant prices for all the countries under scrutiny and are deflated by the annual average rate of change of Harmonised Index of Consumer Prices (HICP). Electricity and gas prices are measured in Euro per MWh, while Final Energy Consumption per capita is measured in 1,000 tones of oil equivalent. $^{16}$

We take logs on both sides of the equation for a more meaningful interpretation in terms of the rate of change (Stern, 2014, p.6). Following Marrero (2010) the

\footnotetext{
${ }^{14}$ It is assumed that an unrestricted set of lags will introduce a huge number of instruments, with a possible loss of efficiency. Therefore, only 3 to 6 lags are to be used in constructing the GMM instruments. See also Polemis and Fotis (2013) and footnotes therein.

15 We also estimate the following equation: $\log F E C_{t, i}=\alpha+\alpha_{1} \log E P_{t, i}+\alpha_{2} \log G P_{t, i}+\alpha_{3} G R_{t, i}+\alpha_{4} G R_{t, i}^{2}+a_{5} G R_{t, i}^{3}+b_{1} F E C_{t, i}(-1)+\varepsilon_{t, i}$. However, the estimated coefficient of $b_{1}$ is statistical insignificant (Robust Std. Error: 0,097; p-value: 0,38). The same results we get from the estimated coefficient of $a_{5}$ (Robust Std. Error: 0,00; p-value: 0,70). Therefore, in this paper we do not employ the said reduced form function. The estimated cubic function is available from authors upon request.

${ }^{16}$ For a more detailed explanation of all variables see Table A2 in the Appendix.
} 
country specific terms $\alpha_{i}$ in equation 1 captures all fixed effects inherent in each member state national economy which are either not considered in the empirical model or not directly observed. The error term $\varepsilon_{t, i}$ encompasses random effects which are not considered in the empirical model. According to Arellano and Bond (1991) and Arellano and Bover (1995)/Blundell and Bond (1998) $\alpha_{i}$ and $\varepsilon_{i, t}$ are independently distributed across $i, \varepsilon_{i, t}$ has zero mean and it is independent over $t$ and $i$. Also, it is assumed that $E\left(F E C_{i, 1}, \varepsilon_{i, t}\right)=0$ for $i=1 \ldots \ldots . N$ and $t=2 \ldots \ldots . . T$. The last assumption concerning the initial conditions of environmental indicators in conjunction with the assumptions regarding $\alpha_{i}$ and $\varepsilon_{i, t}$ suffice for a consistent estimation of equation 1 using DPGMM estimators for $T \geq 3$.

According to Dinda (2004), Richmond and Kaufmann (2006), Lopez-Menendez et al. (2014) among others if $a_{3}>0\left(a_{3}<0\right)$ while $a_{4}=0\left(a_{4}=0\right)$ then there is a monotonically increasing (decreasing) relationship between income and per capita $F E C$. If on the other hand $a_{3}>0$ and $a_{4}<0$ then we observe an inverted U-shaped relationship, while if $a_{3}<0$ and $a_{4}>0$ we observe a U-shaped relationship between real per capita GDP growth rate and per capita FEC per capita.

In the case where per capita $F E C$ is a cubic function of per capita income ${ }^{17}$ and $\alpha_{3}>0, a_{4}<0$ and $a_{5}=0$ then we observe an inverted U-shaped relationship between the two variables. The turning point (threshold level) of per capita income

\footnotetext{
${ }^{17}$ In this paper we do not employ a reduced form function in which per capita $F E C$ is a cubic function of income ( $\left.\log F E C_{t, i}=\alpha+\alpha_{1} \log E P_{t, i}+\alpha_{2} \log G P_{t, i}+\alpha_{3} G R_{t, i}+\alpha_{4} G R_{t, i}^{2}+a_{5} G R_{t, i}^{3}+\varepsilon_{t, i}\right)$ since the estimation of coefficient $a_{5}$ is close to zero but statistical insignificant (the p-value of the estimated coefficient $a_{5}$ is 0.28 ). The estimated cubic function is available from authors upon request.
} 
can be calculated as $G D P^{*}=e^{-\frac{\alpha_{3}}{2 a_{4}}} \cdot{ }^{18}$ If, on the other hand, $a_{3}<0, a_{4}>0$ and $a_{5}=0$ then we observe an U-shaped relationship between per capita FEC and income. Besides, if $a_{3}>0, a_{4}<0, a_{5}>0$, then it must be so that it exists an $\mathrm{N}-$ shaped relationship between per capita $F E C$ and income, while if $a_{3}<0, a_{4}>0, a_{5}<0$, an inverted $\mathrm{N}$-shaped relationship exists between the two variables.

The dependent variable of equation (1) expresses the sum of the energy supplied to the final consumers' door for all energy uses per capita (for instance, the sum of final energy consumption in industry, transport, households, services, agriculture, etc.). $E P_{t, i}$ present electricity prices charged to final consumers and $G P_{t, i}$ present the natural gas prices charged to final consumers. The reason we use gas price in the right hand side of equation (1) is to explore the cross-price effects on final energy consumption and to measure the competitive pressure that the price of natural gas may impose on electricity price.

Real per capita GDP growth rate is the final result of the production activity of resident producer units. The squared real per capita GDP growth rate is a measure that aims to capture the changes in per capita FEC trend across national economies. It captures changes in production and consumption patterns which affect the impact of potential real per capita GDP growth rate on energy consumption and comprises a measure of the economic activity, defined as the value of all goods and services produced less the value of any goods or services used in their creation.

We use the percentage ratio of real per capita GDP growth rate rather than other measures of income utilised in previous literature (such as income in physical units;

\footnotetext{
${ }^{18}$ This is the calculated turning point of the logarithmic version of equation (1). If equation (1) is estimated in levels then the corresponding point is given by $G D P^{*}=-\frac{\alpha_{3}}{2 a_{4}}$.
} 
Galli, 1998) since it allows comparisons of the dynamics of economic development both over time and between economies of different sizes and the computed volume changes are imposed on the level of a reference year and therefore growth rate is not inflated by price movements. Besides, in this paper, apart from the aggregate analysis, we follow a sector-by-sector approach (Industry and Household/Services) ${ }^{19}$ to analyse per capita FEC and therefore the choice of real per capita GDP growth rate as an exogenous variable should ameliorate any significant effect of sector specific energy consumption on aggregate real per capita GDP growth rate.

In order to investigate the long-run equilibrium in each sector of the economy separately we employ a variation of equation (1) given by the following equation:

$$
\log F E C_{t, i, s}=\alpha+\alpha_{1} \log E P_{t, i, s}+\alpha_{2} \log G P_{t, i, s}+\alpha_{3} G R_{t, i}+\alpha_{4} G R_{t, i}^{2}+\varepsilon_{t, i, s}^{\prime}
$$

Here, now index $s$ denotes an end-use sector. For our purposes $s$ represents Industry and Household/Services sectors. We use 5 and 4 lags as GMM instruments in estimating equation 2 in the industrial and Household/Services sectors correspondingly. Note that real per capita GDP growth rate does not contain a subscript $s$ since it is not sector specific. In order to to derive the short-run equilibrium we construct the following ECM specifications with 6 lags as GMM instruments: ${ }^{20}$

$$
\begin{aligned}
& \Delta \log F E C_{t, i}=\alpha_{i}+\alpha_{1} \Delta \log F E C_{t, i, t-1}+\alpha_{2} \Delta \log E P_{t, i}^{+}+\alpha_{3} \Delta \log E P_{t, i}^{+}+\alpha_{4} \Delta \log E P_{t, i}^{-} \\
& +\alpha_{5} \Delta \log E P_{t, i, t-1}^{-}+\alpha_{6} \Delta \log G P_{t, i}^{+}+\alpha_{7} \Delta \log G P_{t, i t t-1}^{+}+\alpha_{8} \Delta \log G P_{t, i}^{-}+\alpha_{9} \Delta \log G P_{t, i, t-1}^{-} \\
& +\alpha_{10} \Delta G R_{t, i}^{+}+\alpha_{11} \Delta G R_{t, i, t-1}^{+}+\alpha_{12} \Delta G R_{t, i}^{-}+\alpha_{13} \Delta G R_{t, i, t-1}^{-} \alpha_{14} \Delta G R_{t, i}^{2} \\
& +\alpha_{15} E C M_{t, i}^{+}+\alpha_{16} E C M_{t, i}^{-}+u_{t, i}
\end{aligned}
$$

\footnotetext{
${ }^{19}$ See also Judson et al. (1999), Medlock and Soligo (2001) and Lescaroux (2011).

${ }^{20}$ It is well known in the literature that the methodology proposed by Arellano and Bond (1991) deals with the correlation of the repressors with the individual effect. See, inter alia, Asteriou and Hall (2016), p. 459.
} 
$\Delta \log F E C_{t, i, s}=\alpha_{i}^{\prime}+\alpha_{1} \Delta \log F E C_{t, i, s, t-1}+\alpha_{2}^{\prime} \Delta \log E P_{t, i, s}^{+}+\alpha_{3}^{\prime} \Delta \log E P_{t, i, s}^{+}, t-1$

$+\alpha_{4}^{\prime} \Delta \log E P_{t, i, s}^{-}+\alpha_{5}^{\prime} \Delta \log E P_{t, i, s, t-1}^{-}+\alpha_{6}^{\prime} \Delta \log G P_{t, i, s}^{+}+\alpha_{7}^{\prime} \Delta \log G P_{t, i, s}^{-}$

$++\alpha_{8}^{\prime} \Delta G R_{t, i}^{+}+\alpha_{9}^{\prime} \Delta G R_{t, i, t-1}^{+}+\alpha_{10}^{\prime} \Delta G R_{t, i}^{-}+\alpha_{11}^{\prime} \Delta G R_{t, i, t-1}^{-}$

$+\alpha_{12}^{\prime} \Delta G R_{t, i}^{2}+\alpha_{13}^{\prime} \Delta G R_{t, i, t-1}^{2}+\alpha_{14}^{\prime} E C M_{t, i, s}^{+}+\alpha_{15}^{\prime} E C M_{t, i, s}^{-}+u_{t, i, s}^{\prime}$

Following Marrero (2010), Arellano and Bond (1991) and Arellano and Bover (1995)/Blundell and Bond (1998) $\alpha_{i}\left(\alpha_{i}^{\prime}\right)$ and $u_{t, i}\left(u_{t, i, s}^{\prime}\right)$ are independently distributed across $i, u_{t, i}\left(u_{t, i, s}^{\prime}\right)$ has zero mean and it is independent over $t$ and $i$. That is, we assume that the initial values of $F E C_{t, i}$ are random draws from a distribution with a common mean, i.e. $F E C_{1, i}=\mu+u_{t, i}\left(u_{t, i, s}^{\prime}\right)$, where $u_{t, i}\left(u_{t, i, s}^{\prime}\right)$ is assumed to be independent of cross-section (units) specific effects $\left[E\left[F E C_{1, i}, u_{t, i}\left(u_{t, i, s}^{\prime}\right)\right]=0\right.$ for $i=1 \ldots \ldots . N$ and $t=2 \ldots \ldots . T]$. Therefore, the impact of the initial values of $F E C_{1, i}$ on current observations vanishes with $t$ (Pesaran 2015, p. 677). The above mentioned assumptions concerning the initial conditions of per capita FEC in conjunction with the assumptions regarding $\alpha_{i}$ and $u_{t, i}\left(u_{t, i, s}^{\prime}\right)$ suffice for a consistent estimation of equations 3 and 4 using DPGMM estimator for $T \geq 3$.

Equation (3) is the basic energy demand function in order to derive the short-run equilibrium and equation (4) is the sector-specific demand function. As in equation (2) $s$ represents the Industry and Household/Services sectors, and $\Delta$ denotes the first difference operator. In the above asymmetric ECMs, changes in prices (electricity and gas prices) and fluctuations in the real per capita GDP growth rate are split into positive and negative changes, respectively. In other words short-run asymmetry is captured by similarly decomposing prices and real per capita GDP growth rate changes into $\Delta x_{t}^{+}=x_{t}-x_{t-1}>0$ and $\Delta x_{t}^{-}=x_{t}-x_{t-1}<0$ for $\mathrm{x}=\mathrm{EP}, \mathrm{GP}, \mathrm{GR}$. Hence $\Delta \log \mathrm{EP}^{+}=\Delta \log \mathrm{EP}$ if $\Delta \log \mathrm{EP}>0$ and 0 otherwise. $\Delta \log \mathrm{GP}^{+}=\Delta \log \mathrm{GP}$ if $\Delta \log \mathrm{GP}>0$ 
and 0 otherwise and $\Delta \mathrm{GR}^{+}=\Delta \mathrm{GR}$ if $\Delta \mathrm{GR}>0$ and 0 otherwise. Obviously, the opposite holds for $\Delta \log \mathrm{CR}^{-}, \Delta \log \mathrm{EP}^{-}, \Delta \mathrm{GP}^{-}$and $\Delta \mathrm{GR}^{-21}$

Finally $\mathrm{ECM}^{+}$and $\mathrm{ECM}^{-}$denote the one-period lagged deviation from the longrun equilibrium (equations 1 and 2) and account for asymmetry in the adjustment process. Similarly $\mathrm{ECM}^{+}=\mathrm{u}_{\mathrm{t}, \mathrm{i}}>0$ and 0 otherwise and $\mathrm{ECM}^{-}=\mathrm{u}_{\mathrm{t}, \mathrm{i}}<0$ and 0 otherwise. The lagged terms in the explanatory variables are chosen by using the Akaike information criterion so as to make $\mathrm{u}_{\mathrm{t}, \mathrm{i}}$ white noise.

\section{Spatial Econometric Modelling}

In this paper we explicitly address the effect of regional externalities on the energy consumption pattern. The reasoning behind such externalities is basically the consumption or production patterns between countries caused by investments in physical and human capital as well as Research \& Development (R\&D). The externalities compensate the mechanisms of decreasing returns to scale to capital accumulation within each economy. Concretely, final energy consumption (captured by FEC in our model) in a given economy may be affected by energy consumption in neighboring economies in terms of geographic or economic criteria. Actually, we focus on spatial and economic externalities by using the following equation:

$$
\log F E C_{i \tau}=\eta_{i}+\lambda \sum_{\substack{j=1 \\ j \neq i}}^{m} w_{i j} F E C_{j \tau}+\mu \sum_{\substack{j=1 \\ j \neq i}}^{m} c_{i j} F E C_{j \tau}+v X_{i \tau}+\omega_{i \tau}
$$

where, $i=1, \ldots, m$ denotes a region, and $\tau=1, \ldots, k$ a time-period. Spatial weights ${ }^{22}$ are denoted by $w$ and economic weights by $c$. So, $W$ and $C$ constitute the respective weight matrices and $X$ is a vector of independent variables that includes, real GDP

\footnotetext{
${ }^{21}$ For instance, inter alia, the command "IF" in Excel may be used in order to decompose the logarithm of prices and real per capita GDP growth rate into positive and negative changes. Before the use of this command we calculate the first difference of each variable under scrutiny.

${ }^{22}$ For alternative specifications of weight matrices see Anselin et al. (1996).
} 
growth rate, gas price and electricity price.

Consequently, we allow for economic spillovers, in addition to standard geographic ones, and in particular the elements $c_{i j}$, to depend on the similarity of their economic characteristics in terms of GDP per capita. The GDP connectivity matrix differs from any distance matrix in two notable ways. First, the GDP matrix consists of weights where the importance of another country $j$ for country $i$ is given by the relative magnitude of GDP per capita. Second, the GDP connectivity matrix weighs high-type partners much more heavily than low-type partners, whereas in the distance matrix, any neighbour of $i$ must always have $j$ as a non-trivial neighbour. Therefore, the elements of the GDP per capita connectivity matrix are defined as $c_{i j}=1-\mid\left(G D P_{j}-G D P_{i}\right) /\left(G D P_{j}+G D P_{i}\right)$ and by construction; this index ranges from 0 to 1 . If GDP per capita is the same between two countries, then $c_{i j}=1$. The elements of the GDP connectivity matrix take the value of 0 if the magnitude of GDP per capita of country $j$ is dissimilar with country $i$, should the difference in GDP values is really significant. Note that this definition of similarity is symmetric in that $c_{j i}=c_{i j}$ and do not vary over time. We construct this similarity matrix on the basis of the distribution of regional GDP per capita. There is also a substantial variability in the average similarity of any given country's GDP with that of all the other countries in our sample.

Our second departure from the standard framework is that the elements of the economic weight matrix, $c_{i j}$, are not constants but an estimable function of economic distance. In particular, we assume that $c_{i j} \propto e^{-\theta c} i j$, where $c_{i j}$ is economic distance between distant regions $i$ and $j$ and $\theta$ is an unknown parameter. Thus, our general specification framework includes more parsimonious specifications or specifications with alternative weights for the border effects. Each variant of equation (5) has been 
estimated in two different ways. In the first approach, consistent estimates of the parameters are obtained using a non-linear regression methodology; with a bound on the parameter space that imposes a positive value for the exponential decay parameter $\theta$ (note that this parameter enters with a negative sign in the econometric model). A negative (zero) value of the parameter would imply that characteristics of a region have a bigger spillover effect the further away they are (are independent of distance). Hence, this parameter is, or should be, positive for meaningful spatial effects. For the same reason, a test of whether $\theta$ is different than zero is not meaningful. Therefore, standard errors are obtained via bootstrapping based on our estimation routine and, by construction, the confidence intervals do not include zero. Asymptotic standard errors, being symmetric in nature, could possibly use confidence intervals that cover zero. This would formally lead to the implication that one cannot reject the hypothesis that the exponential parameter is zero or of the wrong sign, a conclusion that would simply be an artefact of the way symmetric standard errors are computed. The bootstrap standard errors do not suffer from this weakness, but they are asymmetric as a result. However, this first approach does not take into consideration the possible spatial correlation of the disturbance term, resulting in bias of unknown sign in the standard errors.

This Model involves the Maximum Likelihood (ML) estimation ${ }^{23}$ of the parameters and asymptotic standard errors in order to account for the possibility of spatial correlation in the error structure. However, the ML estimates are conditional on the consistent estimate of $\theta$, as obtained under the first estimation approach. In other words, the weight matrix is fixed under the ML approach, but not fixed arbitrarily: it is fixed at a consistent estimate (this is reminiscent of what was known

\footnotetext{
${ }^{23}$ For further details see Brueckner (2003).
} 
in the cross-section literature with non-spherical errors as "feasible GLS"). The use of an estimated $\theta$ for the calculation of the weight matrix understates the ML standard errors. It is necessitated by the fact that the standard ML estimation procedures for spatial models consider fixed weight matrices, but it has the incidental benefit that it sidesteps the issue of the confidence intervals for $\theta$ possibly covering zero. It is worth keeping in mind, though, that this approach still dominates current practice, in which the weight matrix is not only taken as fixed, but also fixed arbitrarily (Keller, 2002).

\section{Empirical results}

\subsection{Stationarity and cointegration of the variables}

To test for the existence of a unit root in a panel data setting, we have used various econometric tests (Breitung t-test, Im, Pesaran and Shin W-test, Fisher type tests, and Hadri test). In all the above tests except for the Hadri test, the null hypothesis is that of a unit root. The W-test is based on the application of the ADF test to panel data, and allows for heterogeneity in both the constant and slope terms of the ADF regression. The ADF and PP tests under the null hypothesis are distributed as $\chi^{2}$ with degrees of freedom twice the number of cross-section units. Moreover, Baltagi and Kao (2001) report that Fisher type tests such as ADF and PP are superior to the $\mathrm{W}$-test in terms of size-adjusted power.

Results for all the tests are presented in Table 3. We observe that the nullhypothesis of a unit root cannot be rejected at $5 \%$ critical value for all of the relevant variables. In other words they are integrated of order one including a deterministic component (intercept). ${ }^{24}$

\footnotetext{
${ }^{24}$ According to the Breitung t-test this is decisively not the case for GPH (gas price in the Household/Services sectors) and GR (real GDP growth rate). However, all the other unit root tests denote that both GPH and GR are I(1).
} 
Table 3: Panel unit root test results ${ }^{\mathrm{a}}$

\begin{tabular}{|c|c|c|c|c|c|}
\hline Variable & $\begin{array}{l}\text { Breitung- } t \\
\quad \text { test }\end{array}$ & $\begin{array}{c}\text { Im, Pesaran } \\
\text { and Shin W-test }\end{array}$ & $\begin{array}{c}\text { ADF-Fisher } \\
\text { Chi-square }\end{array}$ & $\begin{array}{l}\text { PP-Fisher } \\
\text { Chi-square }\end{array}$ & $\begin{array}{c}\text { Hadri } \\
\text { z-statistic }\end{array}$ \\
\hline \multicolumn{6}{|c|}{ Levels } \\
\hline EP & -0.00 & 2.56 & 31.18 & 36.37 & $8.76^{*}$ \\
\hline $\mathrm{EPI}^{*}$ & 0.00 & -1.25 & $84.54^{*}$ & 69.70 & $8.33^{*}$ \\
\hline $\mathrm{EPH} / \mathrm{S}^{* *}$ & -0.00 & 3.56 & 33.79 & 26.98 & $9.11^{*}$ \\
\hline FEC & 0.51 & 0.62 & 62.98 & 63.01 & $8.88^{*}$ \\
\hline FECI $^{*}$ & -1.72 & 1.62 & 40.77 & 46.92 & $8.53^{*}$ \\
\hline $\mathrm{FECH} / \mathrm{S}^{* *}$ & 2.04 & 0.06 & 64.81 & 71.75 & $8.76^{*}$ \\
\hline GP & -0.00 & 0.10 & 46.17 & 55.26 & $8.94^{*}$ \\
\hline $\mathrm{GPH} / \mathrm{S}^{* *}$ & $-1.81^{* *}$ & -0.50 & 54.80 & 53.19 & $8.57^{*}$ \\
\hline GPI $^{*}$ & -0.00 & -0.32 & 63.33 & 70.84 & $8.87^{*}$ \\
\hline GR & $-6.63^{*}$ & 0.08 & 55.30 & 60.60 & $4.88^{*}$ \\
\hline \multicolumn{6}{|c|}{ First differences } \\
\hline$\Delta(\mathrm{EP})$ & $-3.72^{*}$ & $-6.48^{*}$ & $150.816^{*}$ & $152.624^{*}$ & 0.60 \\
\hline$\Delta(\mathrm{EPI})^{*}$ & $-4.08^{*}$ & $-6.52^{*}$ & $160.74^{*}$ & $140.68^{*}$ & 0.60 \\
\hline$\Delta(\mathrm{EPIH} / \mathrm{S})^{* *}$ & $-4.08^{*}$ & $-4.93^{*}$ & $129.48^{*}$ & $132.25^{*}$ & 1.36 \\
\hline$\Delta(\mathrm{FEC})$ & $-5.06^{*}$ & $-9.61^{*}$ & $212.08^{*}$ & $296.92^{*}$ & 7.09 \\
\hline$\Delta(\mathrm{FECI})^{*}$ & $-6.02^{*}$ & $-4.94^{*}$ & $145.36^{*}$ & $148.97^{*}$ & -0.20 \\
\hline$\Delta(\mathrm{FECH} / \mathrm{S})^{* *}$ & $-3.05^{*}$ & $-25.21^{*}$ & $181.89^{*}$ & $231.71^{*}$ & 4.83 \\
\hline$\Delta(\mathrm{GP})$ & $-3.85^{*}$ & $-2.40^{*}$ & $75.64^{*}$ & $113.03^{*}$ & -0.14 \\
\hline$\Delta(\mathrm{GPH} / \mathrm{S})^{* *}$ & $-3.32^{*}$ & $-5.08^{*}$ & $122.77^{*}$ & $129.80^{*}$ & 0.92 \\
\hline$\Delta(\mathrm{GPI})^{*}$ & $-3.15^{*}$ & $-5.38^{*}$ & $130.48^{*}$ & $208.94^{*}$ & 0.10 \\
\hline$\Delta(\mathrm{GR})$ & $-7.37^{*}$ & $-5.45^{*}$ & $146.46^{*}$ & $148.05^{*}$ & -0.71 \\
\hline
\end{tabular}

Notes: ${ }^{\mathrm{a}}$ Under the null hypothesis the Hadri test assumes the absence of a unit root whereas the other unit root tests assume a unit root. The lag lengths were selected by using Schwarz \& Modified HannanQuinn criteria with an individual intercept as an exogenous regressor. Significant at ${ }^{*} 1 \%$ and ${ }^{* *} 5 \%$ respectively.

The explanation of the variables is given in Table A2 in the Appendix. *I stands for Industry sectors, ${ }^{* *} H / S$ stands for Household \& Services sectors.

Source: Authors' elaboration

The next step is to examine if there is a cointegrated relationship between the non-stationary variables of the models. The reason for using cointegration techniques is that non-stationary time series result to spurious regressions and hence do not allow statistical interpretation of the estimations. In order to overcome this problem, we apply the Johansen (1992) technique. The results are presented in Table 4. This method allows us to examine whether there is a long-run co-movement of the variables. The maximum-likelihood eigenvalue statistics indicate that the null hypothesis (no cointegration) is rejected at $1 \%$ level for all the sample countries. Therefore, the said tests and the estimated likelihood ratio tests depict that there is (at least) one cointegration vector for each model. 
Table 4: Johansen Fisher panel cointegration test results ${ }^{\mathrm{b}}$

\begin{tabular}{|c|c|c|}
\hline \multirow[t]{2}{*}{ Series } & \multicolumn{2}{|c|}{ Johansen Fisher Panel Cointegration Test } \\
\hline & Trace statistic & Maximum eigenvalues \\
\hline EP-FEC & $\begin{array}{c}357.3^{*}[\mathrm{r}=0] \\
139.00^{*}[\mathrm{r}=1]\end{array}$ & $\begin{array}{c}\left.327.6^{*}{ }^{*} \mathrm{r}=0\right] \\
139.00^{*}[\mathrm{r}=1]\end{array}$ \\
\hline EP-GR & $\begin{array}{l}417.8^{*}[\mathrm{r}=0] \\
171.5^{*}[\mathrm{r}=1]\end{array}$ & $\begin{array}{l}376.0^{*}[\mathrm{r}=0] \\
171.5^{*}[\mathrm{r}=1]\end{array}$ \\
\hline EP-GR2 & $\begin{array}{l}437.5^{*}[\mathrm{r}=0] \\
133.0^{*}[\mathrm{r}=1]\end{array}$ & $\begin{array}{l}421.6^{*}[\mathrm{r}=0] \\
133.0^{*}[\mathrm{r}=1]\end{array}$ \\
\hline EPH-FECH & $\begin{array}{l}387.7^{*}[\mathrm{r}=0] \\
123.1^{*}[\mathrm{r}=1]\end{array}$ & $\begin{array}{l}365.6^{*}[\mathrm{r}=0] \\
123.1^{*}[\mathrm{r}=1]\end{array}$ \\
\hline EPH-GR & $\begin{array}{l}357.9^{*}[\mathrm{r}=0] \\
109.4^{*}[\mathrm{r}=1]\end{array}$ & $\begin{array}{l}\left.344.9^{*}{ }^{*} \mathrm{r}=0\right] \\
109.4^{*}[\mathrm{r}=1]\end{array}$ \\
\hline EPH-GR2 & $\begin{array}{l}380.8^{*}[\mathrm{r}=0] \\
120.9^{*}[\mathrm{r}=1]\end{array}$ & $\begin{array}{l}360.6^{*}[\mathrm{r}=0] \\
120.9^{*}[\mathrm{r}=1]\end{array}$ \\
\hline EPI-FECI & $\begin{array}{l}397.2^{*}[\mathrm{r}=0] \\
170.9^{*}[\mathrm{r}=1]\end{array}$ & $\begin{array}{l}346.3^{*}[\mathrm{r}=0] \\
170.9^{*}[\mathrm{r}=1]\end{array}$ \\
\hline EPI-GR & $\begin{array}{l}506.9^{*}[\mathrm{r}=0] \\
228.9^{*}[\mathrm{r}=1]\end{array}$ & $\begin{array}{l}439.1^{*}[\mathrm{r}=0] \\
228.9^{*}[\mathrm{r}=1]\end{array}$ \\
\hline EPI-GR2 & $\begin{array}{l}404.5^{*}[\mathrm{r}=0] \\
122.9^{*}[\mathrm{r}=1]\end{array}$ & $\begin{array}{l}387.0^{*}[\mathrm{r}=0] \\
122.9^{*}[\mathrm{r}=1]\end{array}$ \\
\hline FEC-GR & $\begin{array}{l}366.9^{*}[\mathrm{r}=0] \\
142.8^{*}[\mathrm{r}=1]\end{array}$ & $\begin{array}{l}330.7^{*}[\mathrm{r}=0] \\
142.8^{*}[\mathrm{r}=1]\end{array}$ \\
\hline FEC-GR2 & $\begin{array}{l}436.0^{*}[\mathrm{r}=0] \\
145.1^{*}[\mathrm{r}=1]\end{array}$ & $\begin{array}{l}407.0^{*}[\mathrm{r}=0] \\
145.1^{*}[\mathrm{r}=1]\end{array}$ \\
\hline FECH-GR & $\begin{array}{l}369.1^{*}[\mathrm{r}=0] \\
166.3^{*}[\mathrm{r}=1]\end{array}$ & $\begin{array}{l}\left.430.5^{*}{ }^{*} \mathrm{r}=0\right] \\
166.3^{*}[\mathrm{r}=1]\end{array}$ \\
\hline FECH-GR2 & $\begin{array}{l}397.8^{*}[\mathrm{r}=0] \\
153.8^{*}[\mathrm{r}=1]\end{array}$ & $\begin{array}{l}359.4^{*}[\mathrm{r}=0] \\
153.8^{*}[\mathrm{r}=1]\end{array}$ \\
\hline FECI-GR & $\begin{array}{l}340.5^{*}[\mathrm{r}=0] \\
155.4^{*}[\mathrm{r}=1]\end{array}$ & $\begin{array}{l}314.4^{*}[\mathrm{r}=0] \\
155.4^{*}[\mathrm{r}=1]\end{array}$ \\
\hline FECI-GR2 & $\begin{array}{l}423.0^{*}[\mathrm{r}=0] \\
98.15^{*}[\mathrm{r}=1]\end{array}$ & $\begin{array}{l}423.0^{*}[\mathrm{r}=0] \\
98.15^{*}[\mathrm{r}=1]\end{array}$ \\
\hline GR- GR2 & $\begin{array}{l}429.0^{*}[\mathrm{r}=0] \\
125.1^{*}[\mathrm{r}=1]\end{array}$ & $\begin{array}{l}\left.418.6^{*}{ }^{*} \mathrm{r}=0\right] \\
125.1^{*}[\mathrm{r}=1]\end{array}$ \\
\hline GP- GPH & $\begin{array}{c}206.1^{*}[\mathrm{r}=0] \\
51.9[\mathrm{r}=1]\end{array}$ & $\begin{array}{c}207.2^{*}[\mathrm{r}=0] \\
51.9[\mathrm{r}=1]\end{array}$ \\
\hline GP- GPI & $\begin{array}{c}202.9^{*}[\mathrm{r}=0] \\
54.6[\mathrm{r}=1]\end{array}$ & $\begin{array}{c}202.2^{*}[\mathrm{r}=0] \\
54.6[\mathrm{r}=1]\end{array}$ \\
\hline GPH- GPI & $\begin{array}{c}196.3^{*}[\mathrm{r}=0] \\
54.4[\mathrm{r}=1]\end{array}$ & $\begin{array}{c}198.7^{*}[\mathrm{r}=0] \\
54.4[\mathrm{r}=1]\end{array}$ \\
\hline GP- FEC & $\begin{array}{l}316.5^{*}[\mathrm{r}=0] \\
108.1^{*}[\mathrm{r}=1]\end{array}$ & $\begin{array}{l}296.1^{*}[\mathrm{r}=0] \\
108.1^{*}[\mathrm{r}=1]\end{array}$ \\
\hline GP- EPI & $\begin{array}{l}250.0^{*}[\mathrm{r}=0] \\
104.3^{*}[\mathrm{r}=1]\end{array}$ & $\begin{array}{l}229.0^{*}[\mathrm{r}=0] \\
104.3^{*}[\mathrm{r}=1]\end{array}$ \\
\hline GPH- FECH & $\begin{array}{l}275.4^{*}[\mathrm{r}=0] \\
108.5^{*}[\mathrm{r}=1]\end{array}$ & $\begin{array}{l}251.6^{*}[\mathrm{r}=0] \\
108.5^{*}[\mathrm{r}=1]\end{array}$ \\
\hline GPH- EPH & $\begin{array}{c}194.8^{*}[\mathrm{r}=0] \\
79.4^{*}[\mathrm{r}=1]\end{array}$ & $\begin{array}{c}180.5^{*}[\mathrm{r}=0] \\
79.4^{*}[\mathrm{r}=1]\end{array}$ \\
\hline GPI- FECI & $\begin{array}{l}359.1^{*}[\mathrm{r}=0] \\
92.63^{*}[\mathrm{r}=1]\end{array}$ & $\begin{array}{l}350.9^{*}[\mathrm{r}=0] \\
92.63^{*}[\mathrm{r}=1]\end{array}$ \\
\hline GPI - EPI & $\begin{array}{c}277.8^{*}[\mathrm{r}=0] \\
93.8^{*}[\mathrm{r}=1]\end{array}$ & $\begin{array}{l}265.4^{*}[\mathrm{r}=0] \\
93.8^{*}[\mathrm{r}=1]\end{array}$ \\
\hline GP - GR & $\begin{array}{l}320.3^{*}[\mathrm{r}=0] \\
110.9^{*}[\mathrm{r}=1]\end{array}$ & $\begin{array}{l}329.7^{*}[\mathrm{r}=0] \\
110.9^{*}[\mathrm{r}=1]\end{array}$ \\
\hline GPH - GR & $\begin{array}{l}278.5^{*}[\mathrm{r}=0] \\
123.4^{*}[\mathrm{r}=1]\end{array}$ & $\begin{array}{l}254.8^{*}[\mathrm{r}=0] \\
123.4^{*}[\mathrm{r}=1]\end{array}$ \\
\hline GPI - GR & $\begin{array}{l}280.1^{*}[\mathrm{r}=0] \\
107.9^{*}[\mathrm{r}=1]\end{array}$ & $\begin{array}{l}259.1^{*}[\mathrm{r}=0] \\
107.9^{*}[\mathrm{r}=1]\end{array}$ \\
\hline
\end{tabular}

${ }^{b}$ Null hypothesis implies absence of cointegration, while $r$ denotes the number of cointegrating equations with intercept and without deterministic trend. Significant at ${ }^{*} 1 \%$.

Notes: The explanation of the variables is given in Table A2 in the Appendix. ${ }^{*} I$ stands for Industry sectors, ${ }^{* *} H / S$ stands for Household \& Services sectors.

Source: Authors' elaboration 


\subsection{Long-run and short-run estimations from the total sample}

Table 5 presents the Arellano and Bond (1991) (DIFF-GMM) parameter estimates of equations (1), (2), (3) and (4) with standard errors in parentheses, for all sectors under scrutiny and for each end-use sector separately. The estimates of equations (1) and (2) are all highly statistically significant and robust given that they represent structural and not spurious long-run relations.

Particularly, in every econometric model employed we obtain plausible signs of the estimated coefficients. Energy demand is elastic in Industry and Household/Services sectors (-2.24 and -1.03 respectively) since the estimated coefficients of electricity price have the right sign and is above unity. For instance, a $1 \%$ increase of electricity price will cause a fall of energy demand by almost $2.25 \%$ in the industrial sector and by $1.03 \%$ in the Household/Services sectors. ${ }^{25}$ Medlock and Soligo (2001) have also estimated an elastic energy demand for residential and commercial sectors (1.33 in absolute terms) in 15 European countries. However, Polemis and Dragumas (2013) have found energy consumption to be price inelastic with respect to energy price in Greece.

Energy demand is more sensitive in the industrial sector rather than in the Household/Services sectors and this outcome raises concerns whether customers (industrial firms) in the former possess greater bargaining/buyer power than consumers in the Household/Services sectors. Besides, consumers are more and individually less in magnitude than industrial firms, which have the ability to affect more the price policy of energy suppliers. At the same time, the sensitivity of energy demand disclose that energy suppliers possess less (more) bargaining power than industrial firms (consumers).

\footnotetext{
${ }^{25}$ However, when we estimate the econometric model for the whole sectors under scrutiny, the estimated parameter of electricity price is -0.23 .
} 
Table 5: Estimation results of the long-run \& short-run (ECM) models: All sectors, Industry \& Households/Services (DIFF-GMM methodology)

\begin{tabular}{|c|c|c|c|c|c|c|}
\hline & \multicolumn{3}{|c|}{ Short - run Estimations } & \multicolumn{3}{|c|}{ Long -run Estimations } \\
\hline Variables & All Sectors $(I+H / S)$ & Industry $(I)$ & $\begin{array}{c}\text { Households/ } \\
\text { Services }(H+S)\end{array}$ & All Sectors $(I+H / S)$ & Industry $(I)$ & $\begin{array}{c}\text { Households/ } \\
\text { Services }(H+S)\end{array}$ \\
\hline $\mathbf{c}$ & $0.11^{*}(0.00)$ & $-0.08^{*}(0.00)$ & $0.05^{*}(0.00)$ & $2.48^{*}(0.37)$ & $9.94^{*}(1.65)$ & $3.12^{* *}(1.41)$ \\
\hline$(\Delta) \operatorname{FEC}(I, H)_{\mathrm{t}-1}$ & $-0.09^{*}(0.00)$ & $-0.81^{*}(0.00)$ & $-0.48^{*}(0.00)$ & - & - & - \\
\hline$(\Delta) \mathrm{EP}(I, H)^{+}$ & $-0.24^{*}(0.00)$ & $0.16^{*}(0.00)$ & $-0.26^{*}(0.00)$ & - & - & - \\
\hline$(\Delta) \operatorname{EP}(I, H)_{t-1}^{+}$ & $-0.002^{*}(0.00)$ & $-0.13^{*}(0.00)$ & $-0.09^{*}(0.00)$ & - & - & - \\
\hline$(\Delta) \mathrm{EP}(I, H)^{-}$ & $1.81^{*}(0.00)$ & $0.49^{*}(0.00)$ & $-0.26^{*}(0.00)$ & - & - & - \\
\hline$(\Delta) \mathrm{EP}(I, H)_{\mathrm{t}-1}^{-}$ & $2.31^{*}(0.00)$ & $-0.35^{*}(0.00)$ & $-0.74^{*}(0.00)$ & - & - & - \\
\hline$(\Delta) \mathrm{GP}(I, H)^{+}$ & $0.03^{*}(0.00)$ & $-0.36^{*}(0.00)$ & $0.23^{*}(0.00)$ & - & - & - \\
\hline$(\Delta) \mathrm{GP}(I, H)_{\mathrm{t}-1}^{+}$ & $0.12^{*}(0.00)$ & - & - & - & - & - \\
\hline$(\Delta) \mathrm{GP}(I, H)^{-}$ & $0.24^{*}(0.00)$ & $0.78^{*}(0.00)$ & $-0.17^{*}(0.00)$ & - & - & - \\
\hline$(\Delta) \mathrm{GP}(I, H)_{\mathrm{t}-1}^{-}$ & $-0.71^{*}(0.00)$ & - & - & - & - & - \\
\hline$(\Delta) \operatorname{GR}(I, H)^{+}$ & $0.03^{*}(0.00)$ & $0.02^{*}(0.00)$ & $-0.04^{*}(0.00)$ & - & - & - \\
\hline$(\Delta) \operatorname{GR}(I, H)^{+}{ }_{\mathrm{t}-1}$ & $-0.01^{*}(0.00)$ & $0.05^{*}(0.00)$ & $0.01^{*}(0.00)$ & - & - & - \\
\hline$(\Delta) \mathrm{GR}(I, H)^{-}$ & $0.04^{*}(0.00)$ & $-0.05^{*}(0.00)$ & $0.01^{*}(0.00)$ & - & - & - \\
\hline$(\Delta) \mathrm{GR}(I, H)_{\mathrm{t}-1}^{-}$ & $0.02^{*}(0.00)$ & $-0.06^{*}(0.00)$ & $0.03^{*}(0.00)$ & - & - & - \\
\hline$(\Delta) \operatorname{GR2}(I, H)$ & - & $0.01^{*}(0.00)$ & $-0.01^{*}(0.00)$ & - & - & - \\
\hline$(\Delta) \operatorname{GR2}(I, H)_{\mathrm{t}-1}$ & - & $-0.01^{*}(0.00)$ & $-0.01^{*}(0.00)$ & - & - & - \\
\hline$(\Delta) \operatorname{ECM}(I, H)^{+}$ & $1.48^{*}(0.00)$ & $-0.42^{*}(0.00)$ & $0.11^{*}(0.00)$ & - & - & - \\
\hline$(\Delta) \operatorname{ECM}(I, H)^{-}$ & $2.31^{*}(0.00)$ & $-1.37^{*}(0.00)$ & $0.34^{*}(0.00)$ & - & - & - \\
\hline $\mathrm{EP}(I, H)$ & & & & $-0.23^{*}(0.06)$ & $-2.24^{*}(0.40)$ & $-1.03^{* *}(0.48)$ \\
\hline $\mathrm{GP}(I, H)$ & & & & $0.06^{*}(0.04)$ & $0.24^{* *}(0.11)$ & $0.80^{*}(0.26)$ \\
\hline $\operatorname{GR}(I, H)$ & & & & $0.01^{* *}(0.01)$ & $0.10^{*}(0.03)$ & $0.02(0.01)$ \\
\hline GR2 $(I, H)$ & & & & $-0.01^{* *}(0.001)$ & $-0.04^{*}(0.01)$ & $-0.01^{* *}(0.001)$ \\
\hline \multicolumn{4}{|c|}{ Diagnostics } & \multicolumn{3}{|c|}{ Diagnostics } \\
\hline Adj. $R^{2}$ & 0.63 & 0.20 & 0.60 & 0.99 & 0.29 & 0.97 \\
\hline $\begin{array}{l}\text { S.E. of } \\
\text { regression }\end{array}$ & 0.02 & 0.11 & 0.03 & 0.03 & 0.70 & 0.07 \\
\hline Sargan Test & 0.96 & 0.60 & 0.57 & 0.99 & 0.63 & 0.99 \\
\hline $\begin{array}{l}\text { Instrument } \\
\text { Rank }\end{array}$ & 41 & 41 & 43 & 49 & 20 & 29 \\
\hline
\end{tabular}

Notes: When T $>3$ the Sargan test (or the GMM test of overidentifying restrictions) measures the validity of over-identifying restrictions. Under the null hypothesis that the over-identifying restrictions are valid, the Sargan test follows asymptotically the Chi-square distribution (it is distributed as a $\mathrm{x}(\mathrm{p}-$ $\mathrm{k}$ ), where $\mathrm{k}$ is the number of estimated coefficients and $\mathrm{p}$ is the instrument rank (see Sargan 1958 and Hansen 1982). The Sargan test is valid since the number of Instrument Rank is greater than the number of estimated coefficients. The italic numbers in parentheses refer to the Robust Std Errors (Std Errors are adjusted for clustering on crossid). C denotes the constant term. Significant at ${ }^{*} 1 \%{ }^{* *} 5 \%$ and ${ }^{* * *} 10 \%$ respectively.

Source: Authors' elaboration

The estimated coefficients of natural gas price in all sectors under scrutiny $(0.06$, 0,24 and 0.80 for all sectors, Industry and Household/Services sectors respectively) clearly show that natural gas is a demand substitute product for electricity. This is more evident in the Household/Services sectors than in the Industrial sector. Particularly, in the Household/Services sectors the estimated coefficient is 0.80 indicating that a $1 \%$ increase in the price of natural gas will cause a $0.8 \%$ increase of the energy demand. Therefore, as natural gas price increases consumers consume more electricity than gas. 
In the industrial sector the estimated coefficient is 0.24 indicating that a $1 \%$ increase in the price of natural gas will cause a $0.24 \%$ increase of the energy demand. However, in the industrial sector the substitutability between electricity and gas is less pronounced than in the Household/Services sectors showing that firms in industrial sector prefer to use gas than electricity and the market share of the former has been consolidated in high levels.

The less pronounced effect of demand substitutability between electricity and gas is also derived by the relevant estimated coefficient form equation (1). To prove our point, the estimated coefficient is 0.06 implying that a $1 \%$ increase in the price of natural gas will cause a $0.06 \%$ increase of the energy demand. Obviously, the demand substitutability effect in the industrial sector prevails the corresponding effect in the Household/Services sectors

The estimated coefficients of $G R$ from equation 2 show that a non-monotonic relationship between per capita $F E C$ and real per capita GDP growth rate exists according to the theoretical predictions. The estimated coefficient of $G R$ is (highly) statistically significant positive in almost all sectors (except from the Household/Services sectors which is marginal insignificant), while the corresponding coefficient of squared $G R$ is (highly) statistically significant negative in all sectors under scrutiny. That is, the estimated coefficients of real per capita GDP growth rate and squared real per capita GDP growth rate are statistically significant alternating their signs starting from positive to negative. Given these estimations the relationship between per capita FEC and real GDP growth rate exhibits an inverted U-shaped pattern (Medlock and Soligo, 2001; Judson et al., 1999; Lescaroux; 2011).

The turning point (threshold level) of real per capita GDP growth rate is 1 for all the employed sectors of the economy, including the industrial sector and the 
Household/Services sectors. ${ }^{26}$ This means that per capita $F E C$ increases until real per capita GDP growth rate reaches $1 \%$ and then starts to decrease. The empirical results of equations (1) and (2) coincide with the visual inspection of figures 1 and 2.

A possible explanation of the bell shape pattern between per capita $F E C$ and real per capita GDP growth rate may be the new European energy and climate policy since 2007. ${ }^{27}$ Particularly, in 2014 European Commission (EC) presented the key achievements of its energy and climate policy framework (COM 2014, 15 final, p. 2). According to it,

- greenhouse gas emissions in 2012 decreased by $18 \%$ relative to emissions in 1990 and are expected to reduce further to levels $24 \%$ and $32 \%$ lower than in 1990 by 2020 and 2030 respectively on the basis of current policies,

- the share of renewable energy has increased to $13 \%$ in 2012 as a proportion of final energy consumed and is expected to rise further to $21 \%$ in 2020 and $24 \%$ in 2030,

- the EU had installed about $44 \%$ of the world's renewable electricity (excluding hydro) at the end of 2012,

- the energy intensity of the EU economy has reduced by $24 \%$ between 1995 and 2011 whilst the improvement by industry was about $30 \%$,

- the carbon intensity of the EU economy fell by 28\% between 1995 and 2010.

The above-mentioned achievements show that European countries have started to shift towards environmental friendly energy use practices in favour of European energy and climate policy. Particularly, since 2007 all EU member states adopted a new law intended to reduce at least 20\% Greenhouse Gas Emissions (GGE) and to

\footnotetext{
${ }^{26}$ By using the two-regime model by Hansen (2000) and Hansen and Seo (2002) we find that the LS estimate of $\gamma$ is -1.67 . However, this threshold estimate produces non-significant results. Tables and results are not presented here for economy of space; they are available, however, upon request.

${ }^{27}$ The year 2007 has marked as 'the turning point for the European Union's climate and energy policy' (COM 2008, 30 final, p. 2)
} 
achieve $20 \%$ share of renewable energies in EU energy consumption by 2020 . The transmission from commercial energy to renewable energy in nowadays plays a crucial role in determining a bell-shaped relationship between per capita $F E C$ and income in nowadays. At the end of $19^{\text {th }}$ and $20^{\text {th }}$ centuries non-commercial energy were making the bulk of consumption at low-income levels. The substitution of noncommercial energy with oil, gas, electricity and coal was the reason why commercial energy exhibited an inverted U-shaped pattern (Lescaroux (2011)).

We mentioned in section 3.2 that countries with the highest values of average real per capita GDP growth rate (Bulgaria, Czech Republic, Estonia, Latvia, Lithuania, Malta, Poland, Romania, Slovakia and Serbia) present low levels of per capita energy consumption, while countries with low values of average real per capita GDP growth rate (for instance, Finland, Sweden, UK, Norway, Slovenia, Austria and Italy) exhibit high levels of per capita energy consumption. The empirical estimates in Table 2 show that the former evidences marginally prevail to the latter evidences. Figure 3 presents the non-monotonic relationship between real per capita $F E C$ and income for the total sample of countries and sectors of the economy under scrutiny.

Table 5 also presents the parameter estimates of equations (3) and (4), with standard errors reported in parentheses, for all sectors under scrutiny and for each end-use sector separately. The reported estimates are almost all highly statistical significant (except from some estimated coefficients in equation 3). In order to select the appropriate number of lags in the ECM's, we minimise the Akaike Information Criterion.

The short-run results from all sectors under scrutiny in equation 3 indicate larger negative coefficients than positive counterparts for all variables in absolute value. This means that the effects of prices and growth rate decreases are larger than 
those of price increases. In other words, per capita FEC seems to react more to real per capita GDP growth rate decreases and to negative gaps to the equilibrium than to real per capita GDP growth rate increases and positive disequilibrium. Furthermore, the coefficients on the error correction term (positive and negative) are significantly positive.

The short-run own price elasticity is below unity and has the right sign. Galli (1998) has derived the same result since the reported elasticity ranges from 0.1393 (with a random coefficient regressor and a quadratic model) to 0.1625 (with a fixed effect regressor and a quadratic model) and 0.1359 with a fixed effect regressor and a linear model.

Similar results are derived from the estimated coefficients in equation (4) regarding the short-run own price elasticity except from those of electricity price in Household/Services sectors, which have the same magnitude. The corresponding positive coefficients of real per capita GDP growth rate in the industrial sector are higher than its negative counterparts. This means that the effects of prices and growth rate increases are larger than those of price decreases.

Particularly, the estimated coefficient of $G R^{+}$in equation 4 positively (negatively) affects per capita FEC in industrial sector (Household/Services sectors). Our point estimates suggest that a $1 \%$ increase in $G R^{+}$in the short-run raises per capita FEC by approximately $0.2 \%$ in industrial sector and reduces it by approximately $0.4 \%$ in Household/Services sectors. On the contrary, the estimated coefficient of $G R^{-}$negatively (positively) affects per capita $F E C$ in industrial sector (Household/Services sectors). Our point estimates suggest that a $1 \%$ reduction in $G R^{-}$ reduces per capita $F E C$ by approximately $0.5 \%$ in industrial sector and increases it by approximately $0.1 \%$ in Household/Services sectors. Furthermore, the coefficients on 
the error correction term (positive and negative) are significantly positive in

Household/Services sectors and significantly negative in Industrial sector.

\subsubsection{Does the bell shaped pattern describe the relationship between per capita $F E C$ and income in the EU 28 and Eurozone?}

Table 6 presents the Arellano and Bond (1991) (DIFF-GMM) parameter estimates of equations (1), (2) with standard errors shown in parentheses, for all sectors under scrutiny and for each end-use sector separately in the EU28 and Eurozone.

Table 6: Estimation results of the long-run models (1) \& (2): All sectors, Industry \& Households/Services in the EU28 and Eurozone (DIFF-GMM methodology)

\begin{tabular}{|c|c|c|c|}
\hline \multicolumn{4}{|c|}{ Long-run Estimations } \\
\hline \multicolumn{4}{|c|}{ Eurozone } \\
\hline Variables & All Sectors $(I+H / S)$ & Industry $(I)$ & Households/Services $(H+S)$ \\
\hline c & $43.83^{* * *}(25.36)$ & $63.71^{*}(13.03)$ & $45.28^{* *}(18.00)$ \\
\hline $\mathrm{FEC}_{\mathrm{t}-1}(I, H)$ & $0.49^{* *}(0.24)$ & $0.40^{*}(0.84)$ & $0.52^{* * *}(0.24)$ \\
\hline $\mathrm{EP}(I, H)$ & $-0.05(0.03)$ & $-0.09^{* * *}(0.04)$ & $0.01(0.06)$ \\
\hline GP(I,H) & $0.02(0.03)$ & $-0.03(0.02)$ & $-0.05(0.04)$ \\
\hline GR(I,H) & $0.05^{*}(0.01)$ & $0.06^{*}(0.02)$ & $-0.08^{*}(0.03)$ \\
\hline GR2(I,H) & $-0.04^{* * * * *}(0.02)$ & $-0.03^{*}(0.01)$ & $0.02(0.01)$ \\
\hline \multicolumn{4}{|c|}{ EU28 Countries } \\
\hline c & $54.70^{* *}(27.19)$ & $73.23^{*}(24.41)$ & $53.10^{* *}(22.18)$ \\
\hline FEC $_{t-1}(I, H)$ & $0.52^{*}(0.19)$ & $0.42^{*}(0.16)$ & $0.59^{*}(0.21)$ \\
\hline EP(I,H) & $-0.03(0.02)$ & $-0.02(0.20)$ & $-0.03(0.05)$ \\
\hline GP(I,H) & $0.02(0.02)$ & $-0.03(0.02)$ & $0.01(0.04)$ \\
\hline GR(I,H) & $0.05^{*}(0.00)$ & $0.05^{*}(0.01)$ & $-0.04^{*}(0.02)$ \\
\hline GR2(I,H) & $-0.03^{* *}(0.01)$ & $-0.03^{*}(0.01)$ & $0.02(0.01)$ \\
\hline
\end{tabular}

Notes: The dependent variable in all the empirical models is per capita FEC.

Eurozone: EU19 (Austria, Belgium. France, Germany, Greece, Estonia, Ireland, Spain, Italy, The Netherlands, Cyprus, Latvia, Lithouania, Luxembourg, Malta, Portugal, Slovakia, Slovenia, Finland), EU28 (Eurozone plus Bulgaria, Croatia, Hungary, Poland, Romania, Sweden, Czech Republic, Denmark and Great Britain).

The Sargan test is valid since the number of Instrument Rank is greater than the number of estimated coefficients. The italic numbers in parentheses refer to the Robust Std Errors (Std Errors are adjusted for clustering on crossid). $\mathrm{C}$ denotes the constant term.

Significant at ${ }^{*} 1 \%{ }^{* *} 5 \%$ and ${ }^{* * *} 10 \%$ respectively.

Source: Authors' elaboration

On the one hand, table 6 reveals that the relationship between per capita $F E C$ and real per capita GDP growth rate exhibits an inverted U-shaped relationship in the industrial sector and all sectors under scrutiny for both the Eurozone and EU28 member states. The estimated coefficients of $G R$ are (highly) statistically significant positive, while the corresponding coefficients of squared $G R$ are (highly) statistically 
significant negative in both sub-samples and the employed sectors under scrutiny. Besides, the estimated turning points (threshold levels) of real per capita GDP growth rate are all 1 for both sub-samples in the industrial sector and all sectors of the economy, verifying the derived empirical results from Table 5.

On the other hand the derived empirical results from Table 6 regarding the Household/Services sectors in both sub-samples reveal that there is a monotonically decreasing relationship between per capita FEC and income. The estimated coefficients of $G R$ are (highly) statistically significant negative, while the corresponding coefficients of squared $G R$ are (highly) statistically non-significant in both sub-samples indicating a linear relationship between the two variables. Lescaroux (2011) derives a similar result regarding the residential sectors. Particularly, as the residential demand accounts for most of end-use demand the longrun equilibrium path of energy intensity is strictly decreasing. A factor that may affect energy consumption and constitutes one of the main drivers of energy consumption is consumer behaviour.

\subsection{Spatial estimations}

In this section, we present evidence that supports our hypothesis on the role of externalities across countries in the process of energy consumption by estimating the empirical counterpart of Eq. (5). We use energy consumption and a number of explanatory variables to capture the fundamental considerations of the models presented before. It should be stressed that when selecting the aforementioned conditioning variables, we had in mind that observations for each one of them do not differ markedly across nearby countries, so that their inclusion can be considered as a test of robustness for our hypothesis on the role of externalities. This is so, because it could be argued that the spatial lag of the energy consumption captures the effect of 
omitted factors within each region that are spatial and economically correlated depending on the connectivity measure used. Spatial and economic level estimations allow us to study neighbouring effects and provide evidence in relation to the dynamics of each country separately (Deltas and Karkalakos, 2013). Spatial econometric estimations include all countries and study both geographic and economic neighbouring effects.

Estimations for equation (5) with spatial and economic neighbouring effects are presented in Table 7. Spatial effects are defined through the estimation of neighboring consumption of energy component $\left(\lambda \sum_{\substack{j=1 \\ j \neq i}}^{m} w_{i j} F E C_{j \tau}\right)$. They denote neighbouring geographical areas and depict any geographic pattern as far as the consumption of energy. We observe that distance does not affect final energy consumption since the coefficients of neighbouring countries $\left(w_{-} F E C\right)$ are all statistically non-significant.

Table 7: Baseline and Maximum Likelihood Estimation of Energy Consumption

\begin{tabular}{|c|c|c|c|c|c|c|}
\hline & Model A & & & Model B & & \\
\hline Criterion & Distance & $G D P$ & Both & Distance & $G D P$ & Both \\
\hline \multicolumn{7}{|l|}{ Variables } \\
\hline$w_{-} F E C$ & $\begin{array}{c}1.04 \\
(0.95)\end{array}$ & & $\begin{array}{c}0.67 \\
(0.89)\end{array}$ & $\begin{array}{c}0.04 \\
(0.82)\end{array}$ & & $\begin{array}{c}0.19 \\
(0.69)\end{array}$ \\
\hline$c_{-} F E C$ & & $\begin{array}{c}0.88^{*} \\
(0.39)\end{array}$ & $\begin{array}{c}0.92^{*} \\
(0.46)\end{array}$ & & $\begin{array}{c}0.78^{*} \\
(0.41) \\
\end{array}$ & $\begin{array}{c}0.94^{*} \\
(0.47)\end{array}$ \\
\hline$G D P$ & $\begin{array}{l}1.21^{*} \\
(0.61)\end{array}$ & & & $\begin{array}{c}1.55^{*} \\
(0.26)\end{array}$ & $\begin{array}{r}1.12^{*} \\
(0.62)\end{array}$ & $\begin{array}{c}1.74^{*} \\
(0.93)\end{array}$ \\
\hline$E P$ & $\begin{array}{l}-2.02^{*} \\
(1.01)\end{array}$ & $\begin{array}{l}-1.78^{*} \\
(0.94)\end{array}$ & $\begin{array}{l}-1.11^{*} \\
(0.05)\end{array}$ & $\begin{array}{l}-2.10^{*} \\
(1.07)\end{array}$ & $\begin{array}{l}-1.73^{*} \\
(0.84)\end{array}$ & $\begin{array}{l}-1.21 \\
(0.67)\end{array}$ \\
\hline$G P$ & $-1.17^{*}(0.58)$ & $\begin{array}{l}-1.05^{*} \\
(0.53)\end{array}$ & $\begin{array}{l}-1.44^{*} \\
(0.61)\end{array}$ & $\begin{array}{l}-1.06^{*} \\
(0.51)\end{array}$ & $\begin{array}{l}-1.39^{*} \\
(0.68)\end{array}$ & $\begin{array}{l}-1.28^{*} \\
(0.64)\end{array}$ \\
\hline Intercept & $\begin{array}{l}4.03^{*} \\
(1.92)\end{array}$ & $\begin{array}{l}3.11^{*} \\
(1.89)\end{array}$ & $\begin{array}{c}2.42^{*} \\
(1.15)\end{array}$ & $\begin{array}{l}3.97^{* * *} \\
(1.28)\end{array}$ & $\begin{array}{l}3.48^{*} \\
(2.01)\end{array}$ & $\begin{array}{c}2.11^{*} \\
(1.08)\end{array}$ \\
\hline $\mathrm{R}^{2}$ & 0.67 & 0.69 & 0.72 & 0.61 & 0.73 & 0.75 \\
\hline$\lambda$ & & & & 0.0527 & 0.0709 & 0.0585 \\
\hline$\theta$ & 0.1802 & 0.1917 & 0.2314 & 0.2278 & 0.2102 & 0.2237 \\
\hline Log Likelihood & & & & -179.2 & -154.3 & -172.1 \\
\hline
\end{tabular}

Notes: Estimation is conditional on a consistent estimate of $\theta$. The significance of the country dummies is based on log likelihood ratio tests. The intercept in models includes the omitted country dummy and $\lambda$ is significant at $10 *$. Standard errors are in parentheses. Significant at ${ }^{*} 1 \%{ }^{* *} 5 \%$ and *** $10 \%$ respectively.

Source: Authors' elaboration 
However, economic neighbours do positively affect the final energy consumption per country as presented by positive and significant estimated coefficients of the corresponding variable $\left(c_{-} F E C\right)$. Economic effects are defined through the estimation of neighbouring consumption of energy component $\left(\mu \sum_{\substack{j=1 \\ j \neq i}}^{m} c_{i j} F E C_{j \tau}\right)$. They denote neighbouring economic areas and identify similar patterns as far as the consumption of energy. Neighboring economic areas are defined in terms of GDP (similar GDP values per country are neighbors, as described is section 5).

Table 7 illustrates both a baseline model (Model A) and a maximum likelihood model (Model B). Both models use three different types of neighbouring criteria: distance (spatial effects), GDP (economic effects) and both (spatial and economic effects). The positive impact of neighbouring countries, in terms of GDP, in both Model A (0.88) and Model B (0.78) means that similar economic output is accompanied by corresponding energy consumption. The remaining variables do follow the expected sigh and magnitude as discussed at the previous section. The results robustly demonstrate that inter-country externalities do matter, when economic neighbourliness is defined. Economic effects imply strong cross-regional spillovers, which constitute the theoretical framework of our empirical analysis. Also, in both specifications, findings exhibit a strong positive growth influence of GDP. In our empirical model, electricity price and gas price affect regional energy consumption, while there is strong evidence of conditional convergence. In our model, energy consumption of lagging countries is positively affected by a catching-up effect through GDP accumulation. 


\subsection{Parametric Tests for price and growth asymmetric responses}

\subsubsection{Wald Tests \& F-Statistics}

Table 8 depicts the calculated Wald tests and F-statistics testing the asymmetry hypothesis in all sectors. Rejection of the null hypothesis $\mathrm{H}_{0}: \mathrm{ECM}^{+}=\mathrm{ECM}^{-}$implies asymmetric long-run adjustment, whereas short-run asymmetries (price and real per capita GDP growth rate) arise when at least one of the hypotheses $\mathrm{H}_{0}: \mathrm{EP}^{+}=\mathrm{EP}^{-}$or $\mathrm{GP}^{+}=\mathrm{GP}^{-}$or $\mathrm{GR}^{+}=\mathrm{GR}^{-}$, is rejected.

By using the relevant Wald tests, we see that the hypothesis of long-run symmetric adjustment speeds can be rejected at the Industry and Household/Services sectors. Particularly, the results are highly statistically significant for both sectors and statistical significant at $10 \%$ level of significance when we test the price adjustment path in the long-run for all the sectors under scrutiny.

Table 8: Computed Wald and $F$ tests of asymmetric responses

\begin{tabular}{|c|c|c|c|c|c|}
\hline \multicolumn{1}{|c|}{ Sector } & $\begin{array}{c}\boldsymbol{E} \boldsymbol{C M}^{+}=\boldsymbol{E C M} \\
\text { (Symmetric } \\
\text { adjustment } \\
\text { speeds) }\end{array}$ & $\begin{array}{c}\boldsymbol{E} \boldsymbol{P}^{+}=\boldsymbol{E P} \\
\text { (electricity } \\
\text { price } \\
\text { asymmetry) }\end{array}$ & $\begin{array}{c}\boldsymbol{G} \boldsymbol{P}^{+}=\boldsymbol{G P} \\
\text { (gas price } \\
\text { asymmetry) }\end{array}$ & $\begin{array}{c}\boldsymbol{G R}^{+}=\boldsymbol{G R}^{-} \\
\text {(Real GDP } \\
\text { Growth Rate } \\
\text { asymmetry) }\end{array}$ & $\begin{array}{c}\boldsymbol{\alpha}^{+}=\boldsymbol{\alpha}^{-}=\boldsymbol{\beta}^{+}=\boldsymbol{\beta}^{-}=\mathbf{0} \\
\text { (short-run } \\
\text { asymmetry) }\end{array}$ \\
\hline All sectors (Industry/ & 2.99 & 0.78 & 4.93 & 37.35 & 3.54 \\
Households/Services) & $(0.06)$ & $(0.49)$ & $(0.02)$ & $(0.01)$ & $(0.04)$ \\
\hline Industry & 2120363.00 & 1311657.00 & 34340.17 & 2721188.00 & - \\
& $(0.00)$ & $(0.00)$ & $(0.00)$ & $(0.00)$ & - \\
\hline Households/Services & 537005.3 & 1693160.00 & 2141406.00 & 1502990.00 & $(0.00)$ \\
& $(0.00)$ & $(0.00)$ & $(0.00)$ & $(0.00)$ & \\
\hline
\end{tabular}

Notes: $\boldsymbol{\alpha}: \boldsymbol{E P}, \boldsymbol{\beta}: \boldsymbol{G P}$. The italic numbers in parenthesis are the asymptotic P-values.

Source: Authors' elaboration

We reach the same outcome when we test for short-run asymmetries (price and real per capita GDP growth rate) since the null hypothesis $\left(\mathrm{H}_{\mathrm{o}}: \mathrm{EP}^{+}=\mathrm{EP}^{-}, \mathrm{GP}^{+}=\mathrm{GP}^{-}\right.$ and $\mathrm{H}_{\mathrm{o}}: \mathrm{GR}^{+}=\mathrm{GR}^{-}$respectively) can be rejected for both sectors suggesting the existence of asymmetric adjustment speeds in the short-run. The asymmetric electricity price adjustment path in the short-run cannot be sustained as an outcome when we test it from equation (3). However, this outcome is not supported by the Wald tests derived from each sector separately or the F-test concerning the price 
adjustment path derived from equation (3). Particularly, when we simultaneously test the equality of all short-run price parameters of the same lags in all sectors by using the F-statistic, the null hypothesis (equality hypothesis) is rejected for all the sample countries.

From the combined results of the above-mentioned Wald-tests, we conclude that in 34 sample countries there is an asymmetric response of electricity and natural gas prices as well as real per capita GDP growth rate both in the short and the long run respectively. These results are in accord with the empirical results of Table 5 in section 6.2 regarding equations 3 and 4 . Particularly, the derived short-run results from both equations indicate that per capita $F E C$ seems to react more to real per capita GDP growth rate decreases and to negative gaps to the equilibrium than to real per capita GDP growth rate increases and positive disequilibrium. Also, the empirical results of equation 4 show that the effects of prices and growth rate increases are larger than those of price decreases.

\subsubsection{Impulse Response Functions}

To analyse more fully the asymmetric price adjustment path in all sectors of the 34 sample countries, we examine the impulse response functions of final energy consumption to a one standard deviation shock in (electricity and natural gas) prices and real per capita GDP growth rate (Figures 3-5). The estimation results do indicate that per capita $F E C$ tends to respond faster to an increase in (electricity and natural gas) prices and real per capita GDP growth rate in the industrial sector than in the Household/Services sectors. The response difference is statistically significant for both price and real per capita GDP growth rate adjustment paths in all sectors under scrutiny. 
Particularly, the standard deviation of electricity price leads to a decrease in future per capita FEC. This outcome is more evident when the analysis is derived from all sectors (figure 3) and Household/Services sectors (figure 5) than in the industrial sector (figure 4). In the latter sector per capita FEC seems to remain stable in the future (almost stable negative reaction until the second year, negative increase until the fourth year and positive increase, but close to unity, from the fourth year and beyond).

The standard deviation of natural gas price leads to positive and negative reactions in future per capita $F E C$. Regarding all and Household/Services sectors it exhibits a positive reaction until the second year and continues with a positive decrease until the end of the examined period. In the industrial sector it shows a positive increase, at least in the first two years. In any case, these findings are supportive of all earlier econometric estimations.

The standard deviation of real per capita GDP growth rate leads to positive and negative reactions in future per capita FEC. Particularly, the empirical findings from all sectors (see figure 3) indicate a negative decrease until the second year following by a negative increase until the sixth year and stable levels of energy consumption until the end of examined period. Almost the same picture holds in the industrial sector. However, the initial negative decrease remains until the third year. In the Household/Services sectors the initial negative decrease remains until the second year following by a positive increase until the fourth year, a positive decrease until the sixth year and stable levels of consumption until the end of examined period. 
Figure 3: Impulse Response Functions: All Sectors (industry - Households / services)

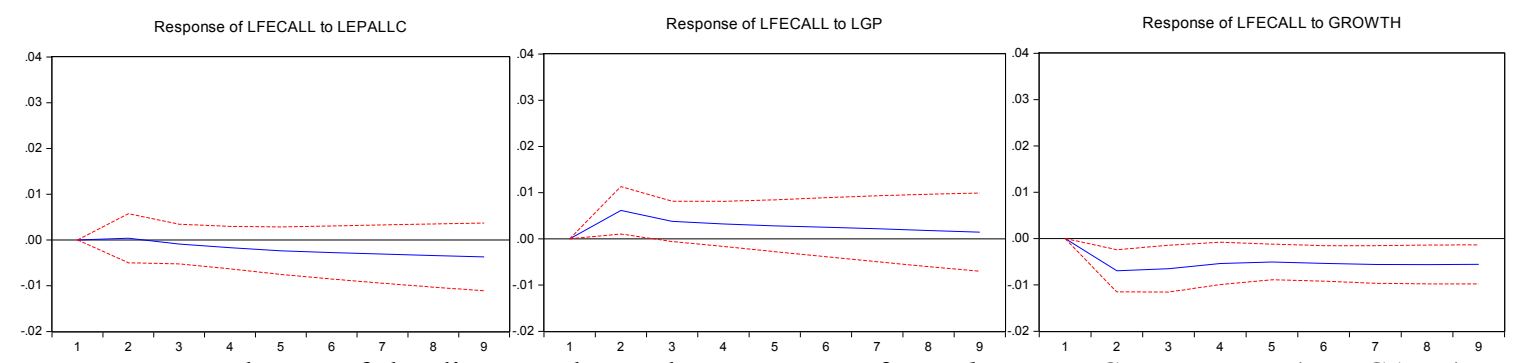

Notes: Each row of the diagram shows the responses of Final Energy Consumption (LFECALL) to a one standard deviation shock of the Electricity Price (LEPALLC), Gasoline Price (LGP) and Real Per Capita GDP Growth Rate (GROWTH). The dotted lines display the corresponding 95\% confidence bounds. All the variables are at 2005 constant prices.

Source: Authors' elaboration

\section{Figure 4: Impulse Response Functions: Industry}
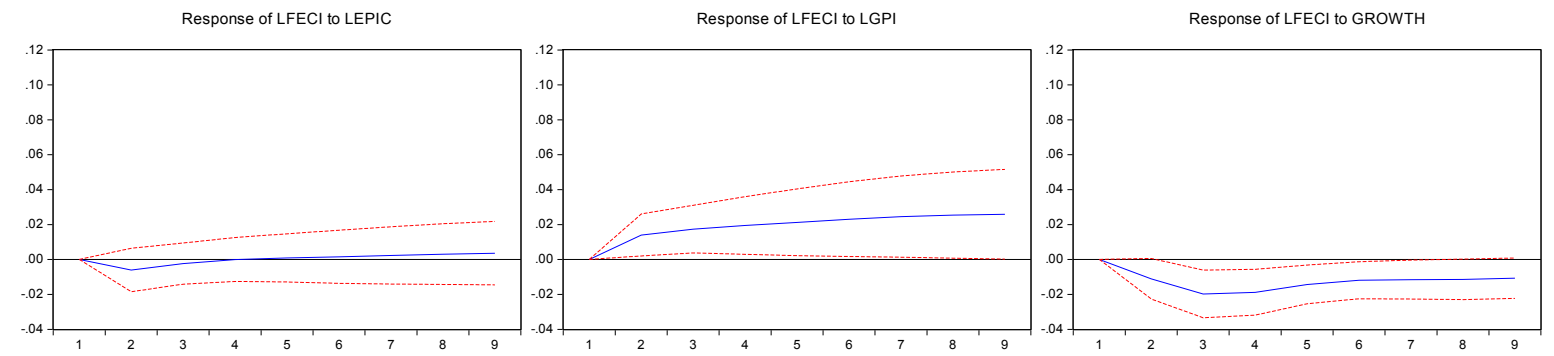

Notes: Each row of the diagram shows the responses of Final Energy Consumption in the industry sector (LFECI) to a one standard deviation shock of the Electricity Price in the industry sector (LEPIC), Gasoline Price in the industry sector (LGPI) and Real Per Capita GDP Growth Rate (GROWTH). The dotted lines display the corresponding 95\% confidence bounds. All the variables are at 2005 constant prices.

Source: Authors' elaboration

\section{Figure 5: Impulse Response Functions: Households/Services}
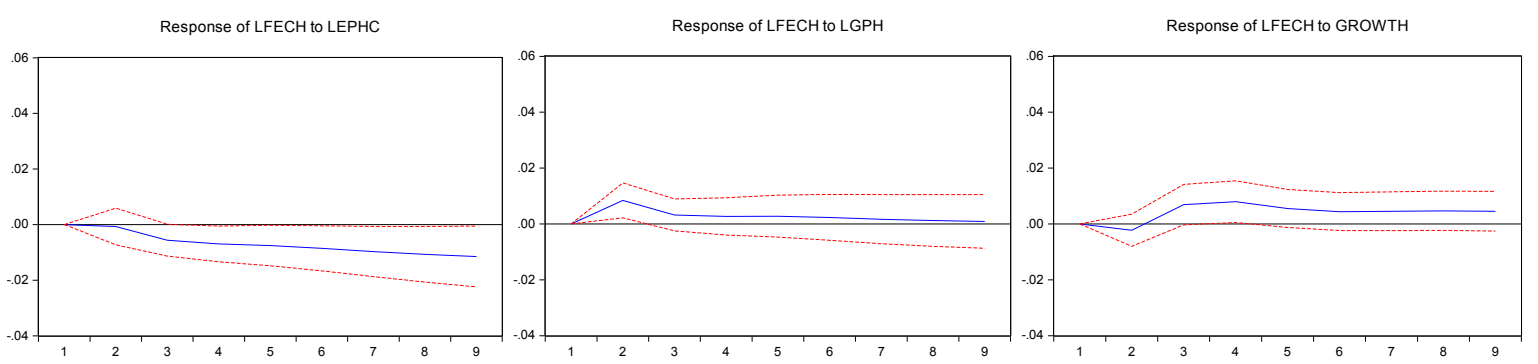

Notes: Each row of the diagram shows the responses of Final Energy Consumption in the household/services sectors (LFECH) to a one standard deviation shock of the Electricity Price in the household/services sectors (LEPHC), Gasoline Price in the household/services sectors (LGPH) and Real Per Capita GDP Growth Rate (GROWTH). The dotted lines display the corresponding 95\% confidence bounds. All the variables are at 2005 constant prices.

Source: Authors' elaboration 


\section{Concluding remarks}

We empirically explore the relationship between per capita $F E C$ and real per capita GDP growth and we investigate the role of price and GDP growth asymmetries as well as regional externalities on FEC. We use an updated panel data set for 34 countries (EU 28 countries 5 candidates - Montenegro, FYROM, Albania, Serbia, Turkey - and Norway) covering the period from 2005 to 2013. A DPGMM approach is used in order to analyse the effect of real per capita GDP growth rate on per capita FEC by estimating short and long-run relationships simultaneously through an ECM. Finally, we employ spatial econometric techniques to examine clustered patterns of energy consumption.

Our research innovates in the sense that it can be viewed as a step towards integrating three strands of the literature: the first focuses on the relationship of energy demand and growth rate; the second examines the effects of (a) symmetric adjustment path of (electricity and natural gas) prices and real per capita GDP growth rate on Final Energy Consumption; the third utilizes spatial econometric techniques to examine clustered patterns of energy consumption. Incidentally, this paper also presents own and cross price elasticities in the industrial and household sectors of the sample countries.

The empirical findings indicate that energy demand is elastic both in the industrial and the household/services sectors, electricity and natural gas are demand substitutes, the relationship between real per capita GDP growth rate and per capita FEC exhibits an inverted U-shape and finally, price (electricity and gas) and GDP growth asymmetries are supported from the employed parametric tests.

The estimated coefficients of real per capita income are statistically significant alternating their signs starting from positive to negative indicating that the 
relationship between per capita FEC and real per capita GDP growth rate exhibits an inverted U-shaped pattern. The empirical findings show that the adoption of the Law in 2007 by all member states in order to reduce at least $20 \%$ greenhouse gas emissions and to achieve $20 \%$ share of renewable energies in EU energy consumption by 2020 have started to transform Europe into a low-carbon, high energy efficiency economy. However, much more have to be done especially from countries that exhibit low values of average real GDP growth rate and high levels of per capita FEC.

The relationship between per capita FEC and real per capita GDP growth rate also exhibits an inverted U-shaped relationship in the industrial sector and all sectors under scrutiny for both the Eurozone and EU28 member states. However, the empirical results regarding the Household/Services sectors in both sub-samples reveal that there exists a monotonically decreasing relationship between per capita $F E C$ and income.

The parametric tests of price (electricity and gas) and GDP growth asymmetries clearly show that long-run symmetric adjustment speeds can be rejected at the Industry and Household/Services sectors. Besides, the existence of asymmetric adjustment speeds in the short-run is also supported from the empirical findings. The asymmetric adjustment paths are more evident in the industrial sector than in the Household/Services sectors. Therefore, we conclude that in 34 sample countries there is an asymmetric response of electricity and natural gas prices as well as real per capita GDP growth rate both in the short and the long run respectively.

The reported estimations for the spatial econometric model indicate that distance does not affect final energy consumption, while economic neighbours do positively affect the final energy consumption per country. It is also evident from the computed cross price elasticities that natural gas imposes competitive pressures on the demand 
of electricity. The reported elasticities are positive for all sectors under scrutiny indicating that policy makers should be sceptical regarding the price policy for both products. Further research on this topic will be very interesting especially in the case where it is combined with the degree of monopolization of the energy market.

In order to eliminate price asymmetries in the euro zone area, government officials should pursue policies to enhance the level of competition in the relevant markets. One suitable policy to protect consumers from welfare loses concerns the implementation of regulatory and behavioural measures as well. To be more specific, the strengthening of the role of the energy suppliers and the elimination of certain barriers to entry in the industrial sector could provide a suitable mechanism to enhance the level of energy imports in the euro zone area.

Another suitable policy in order to prevent the market players in the industrial sector from the imposition of exploitative practices (i.e. price fixing, abuse of dominant position) that hinder the level of competition is linked with a thorough investigation of mergers by the national competition authorities. Mergers in the industrial sector that increases market concentration without creating economies of scale or scope may lead to anticompetitive effects and increase the market power of the incumbents. In such cases where competition is hampered, the government should develop a closely monitoring of the market in order to prevent the marketers from concerted practices.

Policy makers should also consider the provision of the ability in member states to further replace commercial energy with renewable fuels. This policy should be strengthen particularly in countries which exhibit low levels of real GDP growth rate, but continue to consume high levels of per capita FEC. 
Given the above contributions, our analysis could be further expanded in order to tackle a number of constraints which may be addressed in future work. Most specifically, an analysis using more disaggregated data (data from high, medium and low income countries) or data from energy intensity may reach different conclusions. Also, the effect of EU expansion and European tax policy on the energy demand income nexus may shed some light for further evidences and policy implications. Such considerations will capture better the competitive dynamism of the energy sector and lead our research to further outcomes concerning consumer policy. Although, an investigation of this matter would be very useful, it is not possible with the existing available data, and therefore it is left for further research. 


\section{References}

Acaravci, A., Ozturk, I., 2010. On the relationship between energy consumption, CO2 emissions and economic growth in Europe. Energy 35, 5412 - 5420, doi: 10.1016/j.energy.2010.07.009.

Ahn, S.C., Schmidt, P., 1995. Efficient estimation of models for dynamic panel data. Journal of Econometrics 68, 5-27, doi: 10.1016/0304-4076(94)01641-C.

Ajmi, A.N., Hammoudeh, S., Nguyen, K.N., Sato, J.R., 2015. A new look at the relationships between $\mathrm{CO} 2$ emissions, energy consumption and income in $\mathrm{G} 7$ countries: the importance of time variations. Energy Economics 49, 629-638, doi: 10.1016/j.eneco.2015.02.007.

Alvarez, F., Marrero, G.A., Puch L.A., 2005. Air Pollution and the Macroeconomy across European Countries. Working Papers - 10 (FEDEA).

Anderson, T.W., Hsiao, H., 1982. Formulation and Estimation of Dynamic Models Using Panel Data. Journal of Econometrics, 18, 47-82, doi: 10.1016/0304-4076(82)900951.

Ang, B.W., 1987. A cross-sectional analysis of energy-output correlation. Energy Economics, 9, 274-286, doi:10.1016/0140-9883(87)90035-1.

Anselin, L.A., Bera, R., Florax, M.Y., (1996) Simple diagnostic tests for spatial dependence. Regional Science and Urban Economics, 26, pp. 77-104, doi:10.1016/0166-0462(95)02111-6.

Apergis, N., 2016, Environmental Kuznets Curves: New evidence on both panel and country-level $\mathrm{CO}_{2}$ emissions. Energy Economics 54, 263-271.

Apergis, N., Tang, C.F., 2013. Is the energy-led growth hypothesis valid? New evidence from a sample of 85 countries. Energy Economics 38, 24-31, doi:10.1016/j.eneco.2013.02.007. 
Arellano, M., Bond, S., 1991. Some Tests of Specification for Panel Data: Monte Carlo Evidence and an Application to Employment Equations. Review of Economic Studies 58, 277-297, doi: 10.2307/2297968.

Arellano, M., Bover, O., 1995. Another look at the Instrumental variable estimation of Error Component Models. Journal of Econometrics 68, 29-51, doi: 10.1016/03044076(94)01642-D.

Arellano, M., 1989. A Note on the Anderson-Hsiao Estimator for Panel Data. Economic Letters 31, 337-341, doi: 10.1016/0165-1765(89)90025-6.

Arouri, M.E.H., Ben Youssef, A., M'henni, H., Rault, C., 2012a. Energy consumption, economic growth and $\mathrm{CO} 2$ emissions in Middle East and North African countries. Energy Policy 45, 342 - 349, doi: 10.1016/j.enpol.2012.02.042.

Arouri, M.E.H., Ben Youssef, A., M'henni, H., Rault, C., 2012b. Empirical analysis of the EKC hypothesis for sulfur dioxide emissions in selected Middle East and North African countries. Journal of Energy and Development 37, 207 - 226.

Asafu-Adjaye, J., 2000. The relationship between energy consumption, energy prices and economic growth: time series evidence from Asian developing countries. Energy economics 22(6), 615-625, doi:10.1016/S0140-9883(00)00050-5.

Asteriou, D., Hall, G.S., 2016. Applied Econometrics. Palgrave, Third Edition.

Baltagi, H.B., 2005. Econometric Analysis of panel data. John Wiley \& Sons, Third Edition.

Baltagi, H.B., Kao, C., 2001. Nonstationary Panels, Cointegration in Panels and Dynamic Panels: A Survey, in Baltagi, B.H, Fomby, T.B., Hill, R.C. (Eds.), Nonstationary Panels, Panel Cointegration, and Dynamic Panels, 7-51. 
Blundell, R., Bond, S., 1998. Initial restrictions and moment rstrictions in dynamic panel data models. Journal of Econometrics 87, 115-143, doi: 10.1016/S03044076(98)00009-8.

Boyd, G., McDonald, J.F., Ross, M., Hanson, D.A., 1987. Separating the changing composition of US manufacturing production from energy efficiency improvements: A Divisia index approach. The Energy Journal 8(2), 431-448, doi: 10.5547/ISSN0195-6574-EJ-Vo18-No2-6.

Brookes, L.G., 1972. More on the output elasticity on Energy consumption. Journal of Industrial Economics 21(1), 83-92, doi: 10.2307/2098109.

Brueckner, J.K., 2003. Strategic interaction among governments: an overview of empirical studies. International Regional Science Review 26(2), 175-188, doi: $10.1177 / 0160017602250974$.

Caner, M., Hansen, E.B., 2004. Instrumental Variable Estimation of a Threshold Model. Econometric Theory 20, 813-843, doi: 10.1017/S0266466604205011.

Christopoulos, D.K., Tsionas, E.G., 2003. A reassessment of balance of payments constrained growth: results from panel unit root and panel cointegration tests. International Economic Journal 17, 39-54, doi: 10.1080/10168730300000003.

Communication form the Commission to the European Parliament, the Council, the European Economic and social Committee and the Committee of the Regions, 20 20 by 2020 Europe's climate change opportunity, Commission of the European Communities, COM 200830 final, available at http://eur-lex.europa.eu/legalcontent/EN/TXT/PDF/?uri=CELEX:52008DC0030\&from=EN (accessed 13.11.16).

Communication form the Commission to the European Parliament, the Council, the European Economic and social Committee and the Committee of the Regions, A 
policy framework for climate and energy in the period from 2020 to 2030, Commission of the European Communities, COM 201415 final, available at http://eur-lex.europa.eu/legal-content/IT/TXT/?uri=celex:52014DC0015R(01) (accessed 13.11.16).

Coondoo, D., Dinda, S., 2008. Carbon dioxide emissions and income: a temporal analysis of cross-country distributional patterns. Ecological Economics 65, 375385, doi: 10.1016/j.ecolecon.2007.07.001.

Danaeifar, I., 2014. The Estimation Parameters of Kuznets Spatial Environmental Curve in European Countries (A Case Study of CO2 And PM10 and Incidence of Tuberculosis and Life Expectancy at Birth). European Online Journal of Natural and Social Sciences 3(3), 439-448.

Deltas, G. Karkalakos, S., 2013. Similarity of R\&D Activities, Physical Proximity, and R\&D Spillovers. Regional Science and Urban Economics 43(1), 124-131, doi: 10.1016/j.regsciurbeco.2012.06.002.

Desai, D., 1986. Energy-GDP relationship and capital intensity in LDCs. Energy Economics 8(2), 113-117, doi: 10.1016/0140-9883(86)90035-6.

Dinda, S., 2004. Environmental Kuznets Curve Hypothesis: A Survey. Ecological Economics. 49, 431-455.

Donfouet, H.P.P., Jeanty, P.W., Malin, M., 2013. A spatial dynamic panel analysis of the environmental Kuznets curve in European countries. Center for Research in Economics and Management (CREM), Economics Working Paper Archive, 2013-18, 1-16.

Engle, R., Granger, C., 1987. Co-integration and error correction: representation, estimation, and testing. Econometrica 55(2), 251-276, doi: 10.2307/1913236. 
Esteve, V., Tamarit, C., 2012. Threshold cointegration and nonlinear adjustment between $\mathrm{CO} 2$ and income: The Environmental Kuznets Curve in Spain, 18572007. Energy Economics 34(6), 2148-2156, doi: 10.1016/j.eneco.2012.03.001.

European Commission, 2013. EU energy, transport and GHG emissions, trends to 2050, reference scenario 2013. available at https://ec.europa.eu/energy/sites/ener/files/documents/trends_to_2050_update_2013.pdf (accessed 15.11.16).

European Environmental Agency, 2015. Correlation of energy consumption and GDP per person, available at http://www.eea.europa.eu/data-and-maps/figures/correlation-of-per-capita-energy (accessed 20.11.16).

European Union, 2015. Energy production and consumption in 2013. Eurostat News release, $25 / 2015,1-5$.

Fosten, J., Morley, B., Taylor, T., 2012. Dynamic misspecification in the environmental Kuznets curve: evidence from $\mathrm{CO}_{2}$ and $\mathrm{SO}_{2}$ emissions in the United Kingdom. Ecological Economics 76, 25-33, doi: 10.1016/j.ecolecon.2012.01.023.

Fuinhas, J.A., Margues, A.C., 2012. Energy consumption and economic growth nexus in Portugal, Italy, Greece, Spain and Turkey: an ARDL bounds test approach (1965-2009). Energy Economics 34, 511-517, doi: 10.1016/j.eneco.2011.10.003.

Galli, R., 1998. The relationship between energy intensity and income levels: Forecasting long term energy demand in Asian emerging countries. Energy Journal 19(4), 85-105, doi: 10.5547/ISSN0195-6574.

Grossman, G,M., Krueger, A.B., 1995. Economic Growth and the Environment, Quarterly Journal of Economics 110, 353-377. 
Gutierrez, L.H., 2003. The effect of endogenous regulation on telecommunications expansion and efficiency in Latin America. Journal of Regulatory Economics 23(3), 257-286, doi: 10.1023/A:1023412226826.

Hamdi, H., Sbia, R., Shahbaz, M., 2014. The nexus between electricity consumption and economic growth in Bahrain. Economic Modelling 38, 227-237, doi: 10.1016/j.econmod.2013.12.012.

Hannesson, R., 2009. Energy and GDP Growth. International Journal of Energy Sector Management 3(2), 157-170, doi: 101108/17506220910970560.

Hansen, E.B., Seo, B., 2002. Testing for two-regime threshold cointegration in vector error correction models. Journal of Econometrics 110, 293-318, doi: 10.1016/S0304-4076(02)00097-0.

Hansen, E.B., 2000. Sample Splitting and Threshold Estimation. Econometrica 68(3), 575-603, doi: 10.1111/1468-0262.00124.

Hansen, E.B., 1982. Large samples properties of Generalized Method of Moment Estimations. Econometrica 50(4), 1029-1054, doi: 10.2307/1912775.

Holtz-Eakin, D., Selten, T.M., 1995. Stoking the fires: $\mathrm{CO}_{2}$ emissions and Economic Growth, Journal of Public Economics 57, 85-101.

Holtz-Eakin, D., Newey, D., Rosen, S.H., 1988. Estimating Vector Autoregressions with Panel Data. Econometrica 56(6), 1371-1395, doi: 10.2307/1913103.

Jakob, M., Haller, M., Marschinski, R., 2012. Will history repeat itself? Economic convergence and convergence in energy use patterns. Energy Economics 34, 95104, doi:10.1016/j.eneco.2011.07.008.

Jaunky, C.V., 2011. The CO2 emissions-income nexus: Evidence from rich countries. Energy Policy 39(3), 1228-1240, doi: 10.1016/j.enpol.2010.11.050. 
Judson, R.A., Schmalensee, R., Stoker, T.M., 1999. Economic development and the structure of demand for commercial energy. Energy Journal 20, 29-57, .

Keller, W., 2002. Geographic localization of international technology diffusion. American Economic Review 92, 120-142, doi: 10.1257/000282802760015630.

Kijima, M., Nishide, K., Ohyama, A., 2010. Economic models for the environmental Kuznets curve: A survey. Journal of Economic Dynamics \& Control 34, $1187-$ 1201.

Kuznets, S., 1955. Economic growth and income inequality. American Economic Review 45(1), 1-28.

Lee, C.C., 2005. Energy consumption and GDP in developing countries: a cointegrated panel analysis. Energy Economics 27(3), 415-427, doi:10.1016/j.eneco.2005.03.003.

Lescaroux, F., 2011. Dynamics of final sectoral energy demand and aggregate energy intensity. Energy Policy 39(1), 66-82, doi:10.1016/j.enpol.2010.09.010.

López-Menéndez, A., Pérez, R., Moreno, B., 2014. Environmental costs and renewable energy: Re-visiting the Environmental Kuznets Curve. Journal Of Environmental Management 145, 368-373, doi: 10.1016/j.jenvman.2014.07.017.

Maggazino, C., 2015. Energy consumption and GDP in Italy: cointegration and causality analysis. Environment, Development and Sustainability 17(1), 137-153, doi: 10.1007/s10668-014-9543-8.

Mahadevan, R., Asafu-Adjaye, J., 2007. Energy consumption, economic growth and prices: A reassessment using panel VECM for developed and developing countries. Energy Policy 35(4), 2481-2490, doi:10.1016/j.enpol.2006.08.019.

Marrero, A.G., 2010. Greenhouse gases emissions, growth and the Energy mix in Europe. Energy Economics 32, 1356-1363, doi: 10.1016/j.eneco.2010.09.007. 
Mechrara, M., 2007. Energy-GDP relationship for oil-exporting countries: Iran, Kuwait and Saudi Arabia. OPEC Energy Review 31(1), 1-16, doi: 101111/j.14680076.2007.00173.x.

Medlock, K.B., Soligo, R., 2001. Economic development and end-use energy demand. Energy Journal 22(2), 77-105, doi: 10.5547/ISSN0195-6574-.

Metcalf, G.E., 2008. An Empirical Analysis of Energy Intensity and Its Determinants at the State Level. Energy Journal 29(3), 1-26, doi: 10.2307/41323167.

Narayan, S., 2016. Predictability within the energy consumption-economic growth nexus: Some evidence from income and regional groups. Economic Modelling 515, 515-521, doi: 10.1016/j.econmod.2015.12.037.

Nillesen, H.L.P., Haffner, C.G.R., Ozbugday, F.C., 2013. A Global Perspective on the Long-term Impact of Increased Energy Efficiency, in Sioshansi, P. F. (Eds.), Energy Efficiency Towards the End of Demand Growth, pp. 87-110, doi: 10.1016/B978-0-12-397879-0.00003-7.

Ozturk, I., Al-Mulali, U., 2015. Investigating the validity of the environmental Kuznets curve hypothesis in Cambodia. Ecological Indicators 57, 324 - 330, doi: 10.1016/j.ecolind.2015.05.018.

Ouedraogo, N.S., 2013. Energy consumption and economic growth: evidence from the economic community of West African states (ECOWAS). Energy Economics 36, 637-647, doi: 10.1016/j.eneco.2012.11.011.

Panayotou, T., 2000. Economic Growth and the Environment, CID Working Paper No. 56, Cambridge, MA: Center for International Development at Harvard University

Panayotou, T., 1995. Environmental degradation at Different stages of Economic Development. in Iftikhar, A., Doeleman, A.J. (Eds.), Beyond Rio: The 
Environmental Crisis and Sustainable livelihoods in the Third World, ILO Study Series New York: St. Martin's Press, 13-36.

Pesaran, M.H., 2015. Short T Dynamic Panel Data Models, in Pesaran, M. H. (Eds.), Time Series and Panel Data Econometrics, ch. 27, doi: 10.1093/acprof:oso/9780198736912.001 .0001$.

Pirlogea, C., Cicea, C., 2012. Econometric perspective of the energy consumption and economic growth relation in European Union. Renewable and Sustainable Energy Reviews 16(8), 5718-5726, doi:10.1016/j.rser.2012.06.010.

Polemis, L.M., and Stengos, T., Taming the SO2 and NOx emissions: Evidence from a SUR model for the US. Environment and Development Economics (Forthcoming).

Polemis, L.M., Fotis, P., 2013. Do gasoline prices respond asymmetrically in the euro zone area? Evidence from cointegrated panel data analysis. Energy Policy 56, 425-433, doi.org/10.1016/j.enpol.2013.01.001.

Polemis, L.M., and Dagoumas, S.A., 2013. The Electricity Consumption and Economic Growth Nexus: Evidence from Greece. Energy Policy 62, 798-808, doi.org/10.1016/j.enpol.2013.06.086.

Pourgerami, A., Von Hirschhausen, C.R., 1991. Aggregate demand for energy dynamics of energy demand elasticities in non-oil developing countries. The Journal of Energy and Development 14(2), 237-251.

Richmond, A., Kaufmann, R., 2006. Is there a turning point in the relationship between income and energy use and/or carbon emissions?. Ecological Economics 56, 176-189, doi: 10.1016/j.ecolecon.2005.01.011. 
Rodriguez, M., Pena-Boguete, Y., Pardo-Fernardez, J.C., 2016. Revisiting Environmental Kuznets Curves through the energy price lens. Energy Policy 95, 32-41, doi: 10.1016/j.enpol.2016.04.038.

Sargan, J.D., 1958. The estimations of economic relationships using instrumental variables. Econometrica 26(3), 329-338, doi: 10.2307/1907619.

Schäfer, A., 2005. Structural change in energy use. Energy Policy 33, 429-437, doi:10.1016/j.enpol.2003.09.002.

Sephton, P., Mann, J., 2016. Compelling Evidence of an Environmental Kuznets Curve in the United Kingdom. Environmental and Resource Economics 36, 177181, doi:10.1007/s10640-014-9871-z.

Sephton, P., Mann, J., 2013. Further evidence of the environmental Kuznets curve in Spain. Energy Economics 36, 177-181, doi.org/10.1016/j.eneco.2013.01.001.

Shafik, N., Bandyopandhyay, S., 1992. Economic Growth and Environmental Quality: Time-series and Cross-country Evidence. World Bank Publications.

Shahbaz, M., Ozturk, I., Afza, T., Ali, A., 2013. Revisiting the environmental Kuznets curve in a global economy. Renewable And Sustainable Energy Reviews 25, 494502, doi: 10.1016/j.rser.2013.05.021.

Soytas, U., Sari, R., 2003. Energy consumption and GDP: causality relationship in G7 countries and emerging markets. Energy Economics 25, 33-37, doi:10.1016/S0140-9883(02)00009-9.

Soytas, U., Sari, R., 2009. Energy consumption, income, and carbon emissions: challenges faced by an EU candidate member. Ecological Economics 68, 16671675, doi: 10.1016/j.ecolecon.2007.06.014. 
Stern, D.I., 2014. The environmental Kuznets curve: A primer. Centre for Climate Economic \& Policy Working Paper, 1404, Crawford School of Public Policy, The Australian National University.

Wing, I.S., 2008. Explaining the declining energy intensity of the U.S. economy. Resource and Energy Economics 30(1), 21-49.

Wolde-Rufael, Y., 2006. Electricity consumption and economic growth: a time series experience for 17 African countries. Energy Policy 34(10), 1106-1114, doi:10.1016/j.enpol.2004.10.008.

Zilberfarb, B.-Z., Adams F.G., 1981. The energy-GDP relationship in developing countries: empirical evidence and stability tests. Energy Economics 3, 244-248, doi:10.1016/0140-9883(81)90025-6. 


\section{APPENDIX}

Table A1: Method of estimation employed regarding the relationship between energy consumption and economic growth

\begin{tabular}{|c|c|}
\hline Main Literature Review & Method of Estimation \\
\hline Narayan (2016) & Predictive Regression model \\
\hline Nillesen et al. (2013) & ECM - GMM \\
\hline Polemis and Dagoumas (2013) & ECM - OLS, DOLS, FMOLS \& CCR \\
\hline Jakob et al. (2012) & Difference in Difference Estimaror \\
\hline Lescaroux (2011) & Log linear equations - Iterative Least Squares \\
\hline Soytas and Sari (2003) & 2SLS Approach \\
\hline Medlock and Soligo (2001) & Engel curve model - OLS \\
\hline Judson et al. (1999) & ECM - WMG Procedure/RCM \\
\hline Galli (1998) & Cen
\end{tabular}

Notes: ECM: Error Correction Model; GMM: Generalized Method of Moments; OLS: Ordinary Least Squares; DOLS: Dynamic (OLS); FMOLS: Fully Modified (OLS); CCR: Canonical Cointegrating Regression; CCE: Common Correlated Effects; SUR: Seemingly Unrelated Regression; Cup: Continuously-updated; VECM: Vector Error Correction Model; SLS: Step Least Square; WMG: Weighed Mean Group; RCM: Random Coefficient Model

Source: Authors' elaboration of data

Table A2: Variables explanation and list of EU countries

\begin{tabular}{|c|c|c|c|c|c|}
\hline \multicolumn{6}{|c|}{ Variables } \\
\hline $\begin{array}{l}\text { Final Energy } \\
\text { Consumption } \\
\quad(\text { FEC) }\end{array}$ & \multicolumn{5}{|c|}{$\begin{array}{l}\text { Final energy consumption in industry covers all industrial sectors with the exception of the } \\
\text { energy sector, like power stations, oil refineries, coke ovens and all other installations } \\
\text { transforming energy products into another form. Final energy consumption in } \\
\text { households/services covers quantities consumed by private households, small-scale industry, } \\
\text { crafts, commerce, administrative bodies, services with the exception of transportation, } \\
\text { agriculture and fishing. }\end{array}$} \\
\hline $\begin{array}{l}\text { Electricity } \\
\text { Price (EP) }\end{array}$ & \multicolumn{5}{|c|}{$\begin{array}{l}\text { Electricity prices for industrial consumers are defined as follows: Average national price in } \\
\text { Euro per kWh without taxes applicable for the first semester of each year for medium size } \\
\text { industrial consumers (annual consumption between } 500 \text { and } 2000 \mathrm{MWh} \text { ). Electricity prices for } \\
\text { household consumers are defined as follows: Average national price in Euro per kWh } \\
\text { including taxes and levies applicable for the first semester of each year for medium size } \\
\text { household consumers (annual consumption between } 2500 \text { and } 5000 \mathrm{kWh} \text { ). }\end{array}$} \\
\hline $\begin{array}{l}\text { Gas Price } \\
\text { (GP) }\end{array}$ & \multicolumn{5}{|c|}{$\begin{array}{l}\text { Natural gas prices for industrial consumers are defined as follows: Average national price in } \\
\text { Euro per Giga Joule (GJ) without taxes applicable for the first semester of each year for } \\
\text { medium size industrial consumers (annual consumption between } 10000 \text { and } 100000 \mathrm{GJ} \text { ). } \\
\text { Natural gas prices for household consumers are defined as follows: Average national price in } \\
\text { Euro per GJ including taxes and levies applicable for the first semester of each year for } \\
\text { medium size household consumers (annual consumption between } 20 \text { and } 200 \mathrm{GJ} \text { ). }\end{array}$} \\
\hline $\begin{array}{l}\text { Real GDP } \\
\text { Growth Rate } \\
(\text { GR) }\end{array}$ & \multicolumn{5}{|c|}{$\begin{array}{l}\text { Gross domestic product (GDP) is a measure of the economic activity, defined as the value of all } \\
\text { goods and services produced less the value of any goods or services used in their creation. The } \\
\text { calculation of the annual growth rate of GDP volume is intended to allow comparisons of the } \\
\text { dynamics of economic development both over time and between economies of different sizes. }\end{array}$} \\
\hline \multicolumn{6}{|c|}{ Countries } \\
\hline Belgium & Ireland & Cyprus & Netherlands & Slovakia & FYROM $^{*}, * *$ \\
\hline Bulgaria & Greece & Latvia & Austria & Finland & Albania $^{* *}$ \\
\hline Czech Rep. & Spain & Lithuania & Poland & Sweden & Serbia $^{* *}$ \\
\hline Denmark & France & Luxembourg & Portugal & UK & Turkey $^{* *}$ \\
\hline Germany & Croatia & Hungary & Romania & Norway & \\
\hline Estonia & Italy & Malta & Slovenia & Montenegro & \\
\hline
\end{tabular}

Notes: ${ }^{*}$ Former Yugoslav Republic of Macedonia, ${ }^{* *}$ Candidates for potential member states. The (electricity \& gas) prices and energy consumption are per MWh, while annual growth rate of GDP volume is the percentage change on previous year.

Source: http://ec.europa.eu/eurostat/web/energy/data 